Review

\title{
Recent Developments and Challenges of 3D-Printed Construction: A Review of Research Fronts
}

\author{
Robert Guamán-Rivera ${ }^{1}$, Alejandro Martínez-Rocamora ${ }^{2} \mathbb{D}$, Rodrigo García-Alvarado ${ }^{3}$, \\ Claudia Muñoz-Sanguinetti ${ }^{4}$, Luis Felipe González-Böhme ${ }^{5}$ and Fernando Auat-Cheein ${ }^{6, * \text { (D) }}$
}

Citation: Guamán-Rivera, R.; Martínez-Rocamora, A.;

García-Alvarado, R.

Muñoz-Sanguinetti, C.; González-Böhme, L.F.; Auat-Cheein, F. Recent Developments and Challenges of 3D-Printed Construction: A Review of Research Fronts. Buildings 2022, 12, 229. https://doi.org/10.3390/ buildings12020229

Academic Editor: Audrius Banaitis

Received: 20 December 2021

Accepted: 10 February 2022

Published: 17 February 2022

Publisher's Note: MDPI stays neutral with regard to jurisdictional claims in published maps and institutional affiliations.

Copyright: (C) 2022 by the authors. Licensee MDPI, Basel, Switzerland. This article is an open access article distributed under the terms and conditions of the Creative Commons Attribution (CC BY) license (https:// creativecommons.org/licenses/by/ $4.0 /)$.
1 Institute of Engineering Science, Universidad de O'Higgins, Av. Libertador Bernardo O'higgins 611, Rancagua 2820000, Chile; robert.guaman@uoh.cl

2 ArDiTec, Department of Architectural Construction II, IUACC, Higher Technical School of Building Engineering, Universidad de Sevilla, Av. Reina Mercedes 4-a, 41004 Sevilla, Spain; rocamora@us.es

3 GeDIE, Department of Design and Theory of Architecture, Universidad del Bío-Bío, Avda. Collao 1202, Concepción 4030000, Chile; rgarcia@ubiobio.cl

4 DYPCS, Department of Construction Sciences, Universidad del Bío-Bío, Avda. Collao 1202, Concepción 4030000, Chile; clmunoz@ubiobio.cl

5 Department of Architecture, Universidad Técnica Federico Santa María, Av. España, Valparaíso 2340000, Chile; luisfelipe.gonzalez@usm.cl

6 Department of Electronics Engineering, Universidad Técnica Federico Santa María, Av. España, Valparaíso 2340000, Chile

* Correspondence: fernando.auat@usm.cl

\begin{abstract}
In the last few years, scattered experiences of the application of additive manufacturing in the construction of buildings using 3D printing with robots or automated equipment have emerged around the world. These use a variety of procedures and suggest relevant advantages for the construction industry. In order to identify the different processes and features in development in this field and to guide future research and applications, this article presents a review of the literature on the main aspects involved in the use of 3D printing in the construction sector. The review includes state-of-the-art material mixtures, printing technologies, and potential uses, as well as a novel analysis of building strategies, management systems, and benefits stated about this new approach for construction. It reveals progressive experimentation regarding diverse features, with challenges related to the consolidation of procedures and this technology's readiness to participate in the building market.
\end{abstract}

Keywords: 3D-printed construction; robotics; printing materials; additive manufacturing

\section{Introduction}

The construction industry presents many challenges for the development of large-scale customized designs and production, considering that most construction processes have a high economic cost, material waste is abundant, and accident rates are high [1,2]. Recently, technological advances related to emerging technologies, such as robotics, artificial intelligence, data mining, and IoT (Internet of Things), have drawn the attention of researchers, encouraged by the sustainability requirements for this sector [2]. Additive manufacturing provides a disruptive and innovative technology known as 3D printing [3], which can convert a digital design model into a physical object [4].

The advantages that $3 \mathrm{D}$ printing can provide to the construction sector are significant. This technology allows for reaching an optimal use of environmental and financial resources, as well as building aesthetically and structurally complex architectural designs [5]. Additionally, 3D printing of building models opens new opportunities for adopting automation technologies at the construction site [6]. However, the efficiency of automated construction through 3D printing strongly depends on the mechanical properties of cement 
and other components used in modern concrete infrastructure construction. The flexural, tensile, and compressive properties of concrete improve when using nanomaterials and high-performance concrete, which contribute to improve workability, accelerate the printing process, and increase the quality of the binding between printed layers [7-9].

Robotic platforms used in 3D printing provide the solution to many problems related to the design of the structure and the size of printed elements. Regarding the use of robots on-site and off-site, some challenges, such as location or dealing with unexpected events, such as the entry of people or interaction with other robots, must also be tackled. Researchers have proposed solutions to these issues, including new designs of robotic platforms, programming strategies, and the use of perception systems $[8,10,11]$.

The introduction of innovations to conventional construction techniques requires the integration of a variety of expertise, such as civil, systems, electronic, and mechanical engineering; graphic design; and architecture. The contributions of these areas have focused on solving challenges related to structural design, the development of concretebased materials, implementation of algorithms, optimization of 3D-printing models, and implementation of robust systems. Additionally, some studies have been oriented towards sustainable construction, considering that the introduction of 3D printing in this sector will allow for developing of new construction techniques based on eco-efficiency criteria.

The purpose of this paper is to present a systematic review of the impact that 3Dprinting technology has had and will have on building construction and on the optimization of the resources consumed by this sector. We aim to provide information on how 3Dprinting technology has changed conventional building processes and to describe the effects of construction materials, advances in 3D technology, developments in construction systems, and applications currently found worldwide.

The article is organized following the layout of Figure 1. Section 2 addresses the main characteristics of cementitious mixtures for 3D printing of construction elements. In Section 3, the existing additive manufacturing technologies for 3D printing are listed and briefly described. Furthermore, the robotic platforms used in the construction process are also briefly introduced. In Section 4, existing applications of 3D printing are discussed, including the printing of prefabricated components, buildings, houses, walls, and furniture, among others. Section 5 illustrates the building systems, massive walls, and steel reinforcements to support great structural efforts. Section 6 describes the 3D-printing process management system from the robotics viewpoint, and Section 7 discusses the advantages of $3 \mathrm{D}$ printing, considering recent advances and future research needs. Finally, the conclusions are presented in Section 8.

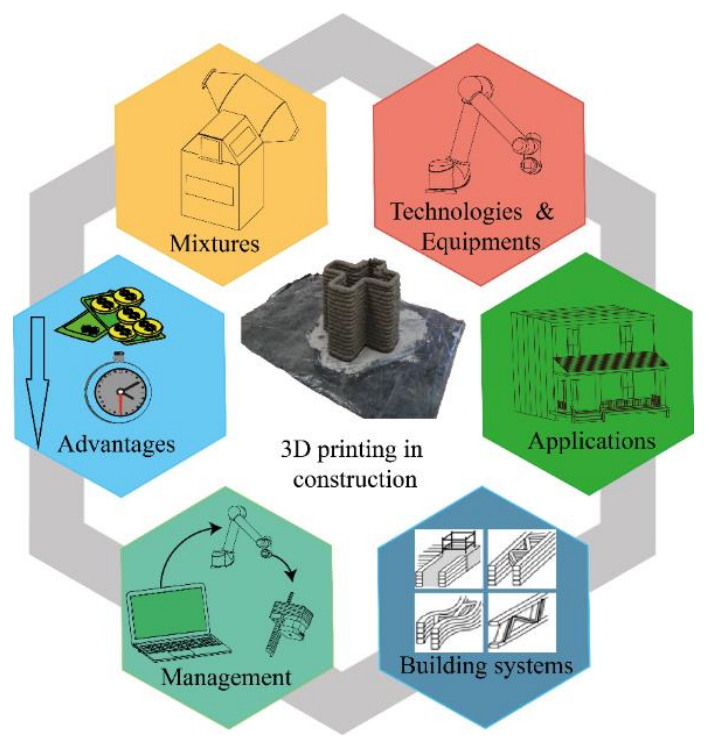

Figure 1. Factors of building construction process using 3D-printing technology. 


\section{Mixtures}

Additive manufacturing (AM) is a digital transformation technology consisting of conforming materials to make objects from a 3D digital model, usually layer upon layer [10]. This term is frequently used in construction as a synonym of $3 \mathrm{D}$ printing, being based on the manufacturing of construction elements by depositing material through a printing head, nozzle, or a similar tool.

The AM processes and the materials handled are closely linked. Therefore, regarding the printing of construction elements, the focus of this section is on aggregate-based cementitious mixtures for elaborating concrete. Concrete has been extensively used in the construction industry because it is easy to process in its fresh state and has high compressive strength in its hardened state [11]. Furthermore, it is compatible with reinforcing steel, which improves its ability to resist the bending required by infrastructure and buildings. For these reasons, it is also the most frequently employed material in AM for buildings [8,12]. However, it usually requires using formwork and other supports, which involve preparation, transport, labor risks, noise, and an additional carbon footprint, among others. AM with concrete substantially reduces these aspects [9,11-15]. Therefore, its use in construction can provide great advantages to the current building industry. For the extrusion of concrete, the materials and process-related parameters cannot be defined independently, as they influence each other. Moreover, new properties, such as pumping capacity, extrusion capacity, layer bonding, and building capacity, must be controlled [16]. The following summary provides the main background on these aspects.

\subsection{Critical Variables of the Concrete Printing Process}

Compared to traditional concrete, 3D-printable concrete requires specific properties, especially in the fresh state, such as reduced slump and fast hardening, due to the absence of formwork that temporarily supports the element while setting [17]. A mixture with reduced slump must have a certain degree of self-compaction, so these two seemingly opposing principles present the challenge of a printable mixture that simultaneously achieves both.

First, the material must allow for being extruded and maintain its shape once deposited on the printing surface; second, the deposited layers must not collapse under the load of subsequent layers; and third, by ensuring the bond strength between layers, better properties are achieved in its hardened state [18]. The use of different types and amounts of cement replacement through the incorporation of mineral additions into the mixture can significantly affect the fresh properties of 3D-printable concrete. In this subsection, we present the different parameters associated with the printing process, based on experimental studies (see [18] for further information).

\subsubsection{Extrudability}

This parameter describes the capacity of a material to be delivered quickly and reliably through an extrusion system. The extrudability can be determined using visual inspection methods, as mentioned by several authors $[16,19,20]$. According to [13], it is mainly affected by the quantity and distribution of dry components in the mixture, thereby requiring a proper rheology of fine aggregates. Furthermore, it is mentioned in the paper [19] that particle size distribution, i.e., binder versus aggregate, influences the extrudability of printable concrete. Likewise, the dosage of mineral and chemical additives, such as superplasticizer, air-entrainer, etc., as well as fibers, are important factors related to this parameter.

\subsubsection{Open Time}

It is the time interval for printing the fluid concrete with the appropriate plasticity [19] that allows the extrusion of stable and consistent layers that maintain their shape. Open time is closely related to the workability of the mixture. The hydration processes of cement and the loss of water from the mixture reduce workability. Another aspect that affects workability is the evaporation of water content under specific environmental conditions 
(temperature, humidity, and wind). In the mixing process, there is a longer thixotropic open time for mixing without motion [16]. Therefore, the preparation and extrusion time has limiting ranges that must be considered.

\subsubsection{Buildability}

It is defined as the capability of fresh concrete to restrict deformation and to avoid the collapse during layer-based AM processes $[16,18,20]$. Adding the proper modifier, e.g., silica fume or nano-clay, to get the appropriate viscosity and normal effort allows establishing of the rheological properties in order to flow correctly and to achieve the required shape stability of fresh printable concrete. On the other hand, the continuous gradation of aggregates will provide concrete with high-performance stress, thus improving the printable mix's buildability [20].

\subsubsection{Shape Retention Factor (SRF)}

Like extrudability, shape retention is a crucial factor for 3D printing of concrete. After extrusion, the material must retain its shape according to the dimension of the extruder, this being expressed through a dimensionless shape retention factor (SRF) [21]. The crosssectional area of the 3D sample before removing the formwork is considered as an SRF equal to one. To obtain a high SRF, the material must have a low slump and a high yield point so that it remains stable under its own weight.

\subsubsection{Contraction Control}

According to [19], contraction is a relevant factor to relate performance to durability of printed concrete, since, when it happens, it affects the dimensional precision and buildability of concrete in its hardened state. The latter can be due to the high amount of cement required, since, in the absence of formwork during the first hours of concrete curing, the excessive loss of water by evaporation increases the risk of contraction during the mixture setting and initial hardening process. In [22], it is mentioned that this contraction is caused by the high content of thin aggregates and a low water-cement ratio, thus requiring one to incorporate superplasticizer (SP) to compensate for it. However, in [23], it is reported that the absence of cement substitute materials and the use of fibers with an addition greater than $0.2 \%$ of the mixture volume can act as a contraction controller.

\subsection{Dosages}

Considering the extrudability and the shape retention of a fresh concrete mixture, a proper mix must be composed of binder material and fine sand aggregates, together with mineral or chemical additives [24]. The most common materials in the binder portion of concrete are ordinary Portland cement (C), fly ash (FA), granulated blast furnace slag, silica fume (SF), and nano-silica, these being combined in different proportions. FA is a by-product obtained from a coal-fired power plant as waste. Class F FA contains more than $70 \%$ silica content, while Class C FA contains $15-30 \% \mathrm{CaO}$. Due to the higher $\mathrm{CaO}$ content, Class C FA shows specific self-hardening characteristics. SF is a by-product obtained from the foundry industry and contains approximately 61 to $98 \%$ silica. Superplasticizers reduce the mixture's viscosity without additional water and are therefore useful to ensure better flowability. Accelerators are useful to provoke a rapid setting of concrete, thereby improving its buildability. However, depending on the concrete mixture, rapid setting can lead to poor adhesion between printed layers. The most common binder contents for 3D-printable concrete, according to several authors, are indicated in Table 1.

In the experience of [19], the choice of the proportions of cement, dispersed micro-silica suspension, and fly ash, in addition to the preparation of an optimized combination of sand aggregates, allowed for obtaining of a high packing density of the solid components, which resulted in adequate rheological behavior and high values of resistance of the tested material. For example, the study by [24] showed the composition of a high-performance mixture (see Table 2) obtained from a series of combinations under the CONPrint3D project 
(Concrete ON-site 3D-Printing), whereby researchers from TU Dresden developed a system for large-scale 3D digital concrete construction.

Table 1. Recommended composition for the binder material of the printing mixture, according to different authors.

\begin{tabular}{cc}
\hline Reference & Contents of Binder Materials \\
\hline$[18]$ & Portland cement $(90 \%)$ and silica fume $(10 \%)$ \\
{$[16,19]$} & Portland cement $(70 \%)$, fly ash $(20 \%)$, and silica fume $(10 \%)$ \\
{$[25]$} & Portland cement (55\%), fly ash (22\%), and silica fume $(23 \%)$ \\
{$[7]$} & Portland Cement $(60-67 \%)$, limestone filler (17-20\%), and silica fume (17-20\%) \\
\hline
\end{tabular}

Table 2. Composition of CONPrint3D's 3D-printing concrete [25].

\begin{tabular}{|c|c|}
\hline Component Type & Dosage $\left(\mathrm{kg} / \mathrm{m}^{3}\right)$ \\
\hline Cement & 430 \\
\hline Fly ash & 170 \\
\hline Dispersed micra silica (solid content $50 \%$ ) & 180 \\
\hline Combined sand $(0.06-2 \mathrm{~mm})$ & 1240 \\
\hline Water & 180 \\
\hline Superplasticizer & 10 \\
\hline
\end{tabular}

From [19], it can be concluded that the best option for printing free-form components was a mixture with a water-to-binder ratio of 0.26 and a binder-to-sand ratio of 3:2, comprising $70 \%$ cement, $20 \%$ fly ash, and $10 \%$ silica fume, plus $1.2 \mathrm{~kg} / \mathrm{m}^{3}$ of micro propylene fibers. This mixture also required $1.083 \%$ of super-fluidifier, with respect to cement weight, to achieve optimal workability.

Most studies on cementitious printing mixtures use fly ash and micro silica as thin material additions. However, fly ash presents characteristics that depend on location, whereas micro silica has a limited supply that cannot be sustained in the long term [26]. Due to this situation, alternatives have arisen in the conventional concrete industry that are still in exploration by researchers. One of these alternative products is metakaolin, which exists in abundance in the Earth's crust. Metakaolin is produced through the calcination of kaolinitic clays. Its cost, which is three times higher than that of cement, remains a disadvantage. Of the reviewed mixtures, approximately $45 \%$ used meta-kaolin and limestone, with a 2:1 ratio. In binder mixtures, these presented better mechanical performance at 7 and 28 days than mortars with 100\% Portland cement [27].

\subsection{Mixture Design}

Material mixtures for 3D-printed construction must be designed according to the performance required for the elements to be executed, as well as to the extrusion process. This design process has been approached by [28] as sequential phases, because these progressively condition different aspects. For example, the structural requirements of the printed component and its integration with reinforcement determine the required mechanical properties and buildability factors. In turn, the pumping and extrusion technologies employed, along with the mixture's storage and preparation method, require establishing additional parameters regarding the rheology of aggregates, the cementitious base, and the additives to be applied. These relationships condition the design of the appropriate mixtures for different sets of elements, equipment, and work contexts. Moreover, the design of mixtures is also conditioned by the interrelationship between the model design to be executed and a series of material and process parameters [29], as shown in Figure 2, considering an integrated structure between printability, buildability, and extrudability, centralized by the thixotropic open time, as expressed in Figure 3. This is complemented by the preparation and application processes, according to the standards and the necessary tests for the execution, as well as for obtaining the performance required for the building elements. 


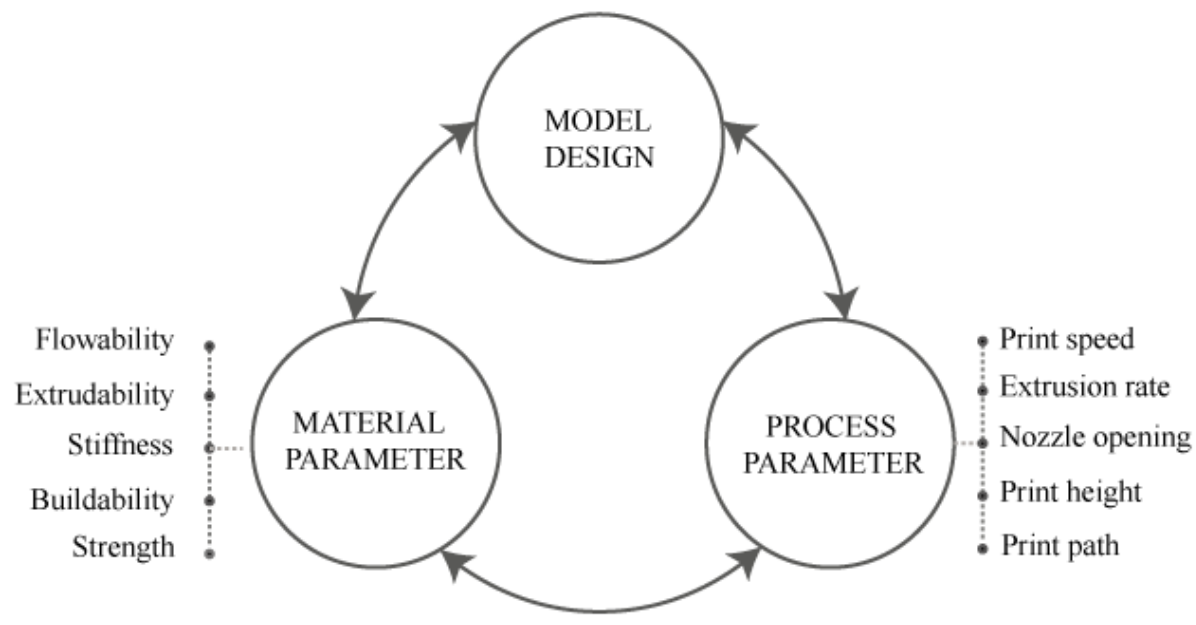

Figure 2. Design parameters and properties of cementitious material containing copper tailings for extrusion-based 3D printing, based on [19].

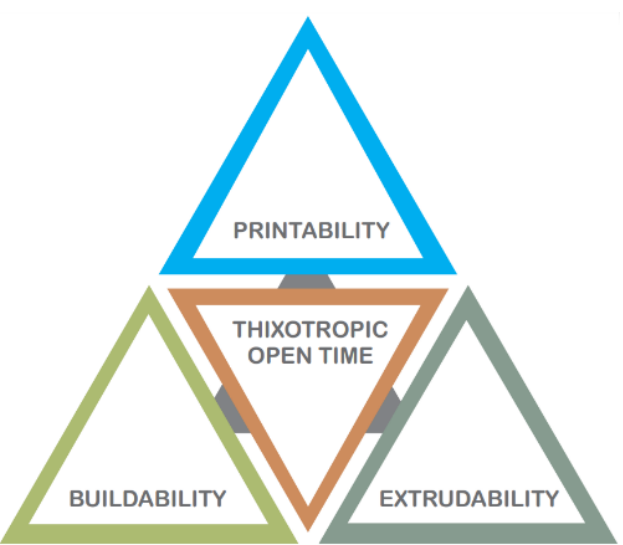

Figure 3. Mix Design, Intellectual Protection Certificate N$^{\circ} 2020-A-4080$, Universidad del Bío-Bío, Chile, based on [28].

\subsection{Addition of Fibers}

In recent years, the first ideas about 3D-printed concrete reinforced with short fibers, glass, carbon, and basalt, with lengths ranging from 3 to $12 \mathrm{~mm}$, have gained visibility, and they have shown an increase in bending strength of up to $30 \mathrm{MPa}$. A study carried out by [30] showed that by incorporating $1 \%$ of fibers in proportion to the mixture's volume, its flexural strength reached values of up to $30 \mathrm{MPa}$, representing an increase of $20 \%$ compared to mixtures without fibers. In addition, [31] noted that to dispense the absence of steel reinforcements, mortars and concretes containing high-performance fibers have shown an increase in flexural properties while providing extra ductility to the printed element. Mixtures based on polymers or clay have also been experimented for printing, both in small and large elements, achieving a complete construction in some cases [28,31,32]. Although these did not show the details of the development, they constitute promising possibilities for $\mathrm{AM}$ in construction.

\section{Technologies and Equipment}

The integration of AM technology with robotic systems can improve production time, accuracy, and precision, and it has allowed the development of customized designs and the reduction of costs and waste materials [32-35]. These advantages can contribute to the rapid construction of buildings in special conditions like natural disasters or housing provision.

Currently, the available AM methods for 3D-printed construction are contour crafting, D-shape, and concrete printing. Contour crafting is a multi-material deposition tech- 
nique, combining an extrusion process and a filling process to build a 3D object layer by layer $[22,33]$. In the case of the D-shape technique, the printing process involves depositing sand with a binder to form a 3D structure [36,37]. Concrete printing is a technique with cement mortar extrusion to build a 3D layered model without using formwork [38,39]. Figure 4 presents a summary of the characteristics of AM methods in large-scale processes, which will be explained in detail.

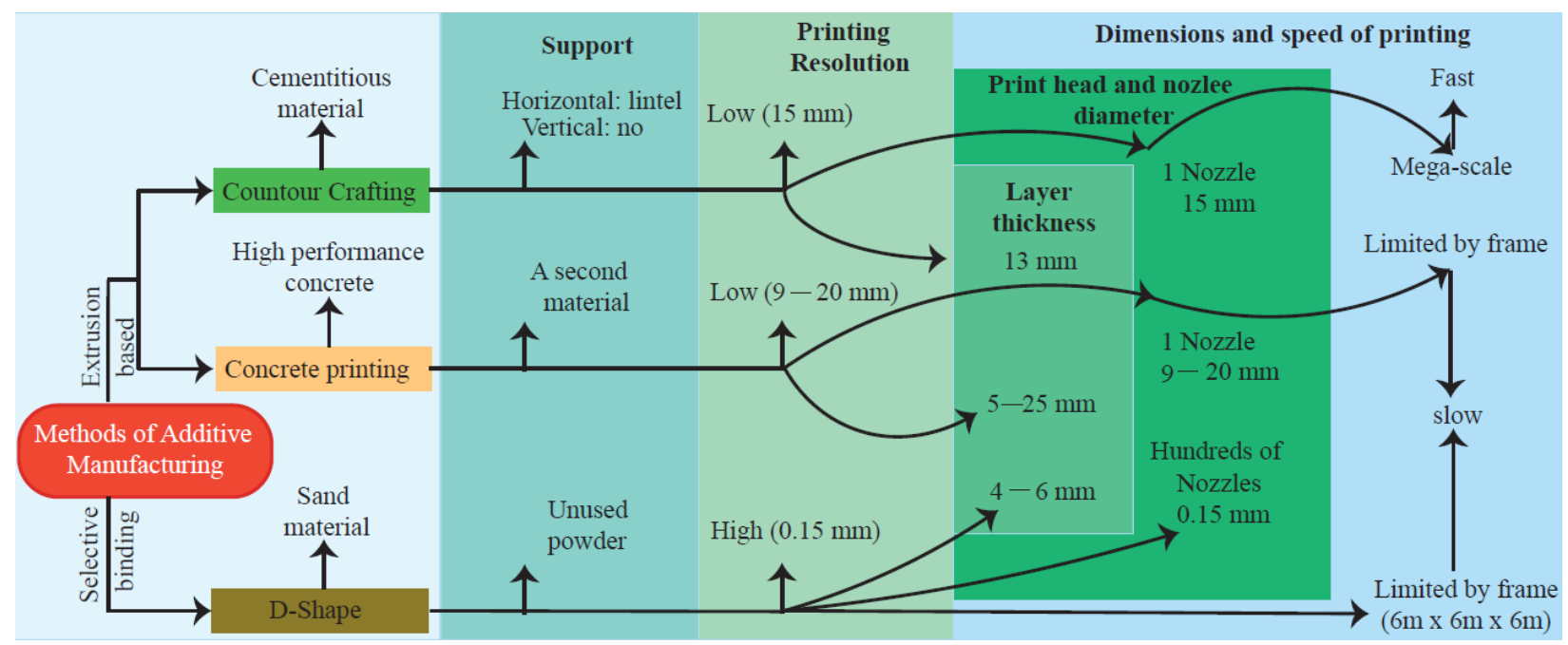

Figure 4. Methods of additive manufacturing.

Considering the printing scale, these techniques present a manufacturing dimension restriction due to their deposition method and mechanical structure. Another important factor in these methods is the printing speed. While contour crafting and concrete printing are fast processes, they have a lower printing resolution and higher layer thickness compared to the D-shape technique, which uses small diameter nozzles that allow for a higher printing resolution [40]. Therefore, each of these methods have their advantages and limitations depending on the applications.

The use of robotic platforms in the construction industry allows for printing of 3D models that are not feasible with conventional AM. Bhatt et al. [41] identified five functional benefits of robots in AM processes and summarized them as follows:

- Multidirectional AM: The control of direction between layers reduces the ladder effect and avoids the use of supports in conventional AM [41,42]. Furthermore, the degrees of freedom of the multi-directional configuration are assigned to the extrusion tool or the equipment's base, thus allowing efficient printing of 3D models.

- Conformal AM: The strength of an element printed with AM techniques depends on the method of material deposition and the consistency between layers. The parameters to be considered are time, use of support structure, and printing direction, which can be efficiently managed through path generation algorithms [43].

- Assembling prefabricated components in AM: The integration of components during printing requires interaction between the process, the robot, and workers. Combining assemblies with human assistance generates orientation and positioning errors. To avoid these errors, the use of autonomous robots with a high degree of freedom allows efficient maneuverability within the workspace [41].

- Formwork-less AM: Improving the efficiency of the construction industry is one of the main challenges today. The use of formwork to produce concrete elements is a problem that generates delays and economic costs. Printing by extrusion makes it possible to eliminate the use of formwork. However, the model's printing efficiency depends on how efficient the control is between the printing tool and the equipment base [41]. 
- Large-Scale: Printing systems in AM are usually gantry systems, robotic arms, and mobile manipulators. The challenge of these systems is to achieve large-scale printing. Based on this, gantry systems and robotic arms have a limited printing volume. Furthermore, the difference between these systems is that the robotic arm makes better use of its workspace. Despite mobile manipulators covering a larger workspace, these have low accuracy and low repeatability due to the use of a mobile base [41].

Several works have reported the use of robots in AM, considering different mechanisms and degrees of freedom of these platforms [44-46]. Table 3 specifies the robot platforms used for 3D-printing purposes in studies focused on different AM categories (these platforms are marked with *).

Table 3. Printing systems used for additive manufacturing categories (the * stands for content).

\begin{tabular}{ccccc}
\hline AM Category & Manipulator & Mobile Manipulator & Gantry System & References \\
\hline Sheet lamination & $*$ & & $*$ & {$[45,47]$} \\
VAT photopolymerization & $*$ & $* 48]$ & {$[46]$} \\
Direct energy deposition & $*$ & $*$ & $*$ & {$[17]$} \\
Material extrusion & $*$ & $*$ & $*$ \\
\hline
\end{tabular}

The integration of robotic structures in the construction industry has made it possible to carry out printed concrete applications using 3D-printing technology on a large scale $[9,14]$. Table 4 shows a summary of the use of automated platforms in existing experiences, classified into polyarticulated platforms, mobile robots, and customized systems (gantry systems) [49]. These systems have limitations in terms of transport and installation, depending on the size of structures, assembly time, and workspace.

The use of robotic systems makes it possible to optimize 3D design topologies, to create more efficient structures, and to reduce material waste [50,51]. Moreover, the integration of robots into the construction process increases the ability to build complex geometries in less time and reduces the cost of production by improving quality and reliability, as reported in [52-55].

Table 4. Automated platforms used in 3DCP.

\begin{tabular}{|c|c|c|c|c|}
\hline & Automated Platforms & Applications & Advantages & Disadvantages \\
\hline \multirow{4}{*}{ 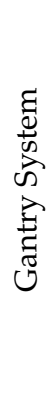 } & & $\begin{array}{l}\text { Construction of a bridge whose size is } \\
\qquad 25.1 \mathrm{~m} \mathrm{[56].}\end{array}$ & Large-scale printing & $\begin{array}{l}\text { Size of the } \\
\text { structure }\end{array}$ \\
\hline & & $\begin{array}{l}\text { Test printing of concrete arches } \\
\text { without formwork [52]. }\end{array}$ & $\begin{array}{l}\text { Efficient use of } \\
\text { workspace }\end{array}$ & Assembly time \\
\hline & & $\begin{array}{l}\text { Construction of custom designs using } \\
\text { 3D printing to model complex } \\
\text { geometries [57]. }\end{array}$ & & $\begin{array}{l}\text { Specific print } \\
\text { designs }\end{array}$ \\
\hline & & $\begin{array}{l}\text { 3D printing of concrete structures. } \\
\text { Gantry sytem [58]. }\end{array}$ & & \\
\hline
\end{tabular}


Table 4. Cont.

\begin{tabular}{|c|c|c|c|c|}
\hline & Automated Platforms & Applications & Advantages & Disadvantages \\
\hline \multirow{7}{*}{ 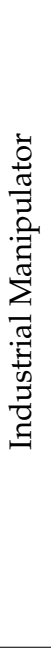 } & & Construction of a house $[59,60]$. & & \\
\hline & & $\begin{array}{l}\text { Design of a post-tensioned concrete } \\
\text { slab post-tensioned [61]. }\end{array}$ & Easy transport & Workspace \\
\hline & & $\begin{array}{l}\text { Construction of complex } \\
\text { structures }[32,51,54,55] \text {. }\end{array}$ & $\begin{array}{l}\text { Complex print } \\
\text { designs }\end{array}$ & $\begin{array}{c}\text { Limitations on } \\
\text { manipulator } \\
\text { movement }\end{array}$ \\
\hline & & $\begin{array}{l}\text { On-site construction of a } \\
\text { mesh mold [62]. }\end{array}$ & $\begin{array}{l}\text { Lower printing } \\
\text { complexity }\end{array}$ & \\
\hline & & $\begin{array}{l}\text { Reinforced concrete columns printed } \\
\text { with 3D technology [63]. }\end{array}$ & & \\
\hline & & $\begin{array}{c}\text { Design and printing of a } \\
\text { double-curved facade } \\
\text { prototype }[64,65] .\end{array}$ & & \\
\hline & & Industrial manipulator [66]. & & \\
\hline \multirow{3}{*}{ 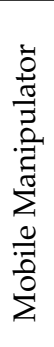 } & & Construction of concrete facades [64]. & $\begin{array}{l}\text { Customized printing } \\
\text { designs workspace }\end{array}$ & $\begin{array}{l}\text { Higher printing } \\
\text { complexity }\end{array}$ \\
\hline & & $\begin{array}{l}\text { Construction of complex concrete } \\
\text { geometries }[67,68] .\end{array}$ & $\begin{array}{l}\text { Integration of a linear } \\
\text { or circular axis and a } \\
\text { mobile robot }\end{array}$ & \\
\hline & & Mobile manipulator [67]. & $\begin{array}{l}\text { Integration of a linear } \\
\text { or circular axis and a } \\
\text { mobile robot }\end{array}$ & \\
\hline
\end{tabular}

\section{Applications}

Scientific articles that address a general overview of 3D-printed construction are mostly dedicated to expose this technology and its implications, presenting examples of applications with different approaches, sometimes combined. Some studies declare that 3D-printed construction can execute elements with certain attributes, for example, prefabricated, more complex, or optimized [14,38,69-72]. Others state that it can execute different types of buildings or components (houses, walls, furniture, etc.), showing examples and/or discussing general conditions for their correct execution $[1,17,36,40,60,62,73-75]$.

The aforementioned studies mention advantages and/or some potentials of this technology related to specific capabilities or experiences without analyzing them exhaustively. For example, they repeatedly refer to the capacity to execute elements directly on-site, such as at the factory (i.e., off-site), with these being opposite approaches, which imply different procedures and strategies that are not differentiated. Furthermore, some studies state that 3D-printed construction can be applied in dangerous environments and highlight the relevance of this technology for war or recovery situations from catastrophes due to its speed and reduction of manpower needs. Likewise, it is frequently stated that this technology can be used to execute new buildings or to repair damages in existing ones. However, only a few strategies have been thoroughly described. Additionally, some researchers declare that 3D-printed construction is useful for making elements with specific characteristics, for example, structurally optimized; thermal- or acoustic-resistant; or with non-repetitive elements, characterized for their variability, adaptation to unique requirements, or high precision.

Documents mentioning or showing 3D-printed building elements usually show pieces or complete enclosures with different sizes or functions, for example, straight or curved walls $[19,37,61,76]$ and columns $[50,76,77]$ but rarely beams [74] and, very occasionally, ceilings, floors, and a variety of smaller objects. As complete constructions, the following examples present urban furniture for sitting or partitions [22]; tiny buildings, such as 
cabins or pavilions, with unique interior spaces and partial openings; several examples of individual one-story detached houses with 3D-printed walls, combined with conventional elements [50], including roofs [36,76]; and pedestrian bridges [1] and large buildings with different uses $[1,50,61,77]$. The destinations of 3D-printed components also differ for exhibition; transport; or accommodation of different functions, such as storage, work, social activities, or recreational housing, among others. A list of attributes and related values are mentioned in diverse documents, as shown in Table 5.

Table 5. Types of applications according to different attributes.

\begin{tabular}{ccc}
\hline Attribute & Values & References \\
\hline Location & On-site-Off-site & {$[70,77]$} \\
Safety & Harsh-Common & {$[14]$} \\
Existence & New-Repair & {$[38]$} \\
Structure & Regular-Optimized & {$[14,69]$} \\
Indoor performance & Regular-Optimized & {$[29,78]$} \\
Reproduction & Regular-Customized & {$[69]$} \\
Precision & Regular-Tolerance & {$[79]$} \\
Shape & Regular-Complex & {$[14,69]$} \\
Material & Homogenous-Multiple & {$[38,69]$} \\
System & Homogenous-Hybrid & {$[14]$} \\
Resources & New-Recycled & {$[69]$} \\
Management & Fragmented-Digital flow & {$[69]$} \\
\hline
\end{tabular}

Some studies that focused on the execution of prefabricated elements showed components such as panels [69] and beams [74]. Furthermore, optimized pieces such as structural supports $[69,71]$ or insulation improvements can be found in the literature. Regarding complex forms, sculptures [17,69], furniture [69], and a variety of components [40] have been developed. Among the exhibitions of elements or complete constructions, examples of works carried out by Win Sun from China stand out, with different typologies of houses from 130 to $1100 \mathrm{~m}^{2}$, buildings up to six floors, and offices $[10,17,41,50,59,63]$. DUS Architects from the Netherlands worked on a housing project based on 3D-printed components with polypropylene and assembled with metal elements $[10,50,63]$. In Russia, Apis Cor developed a $132 \mathrm{~m}^{2}$ house [1], while HuaShang Tengda developed a two-story $400 \mathrm{~m}^{2}$ home $[17,80]$. Cybe built a $168 \mathrm{~m}^{2}$ laboratory in Dubai, and Total Kustom has developed smaller projects in the USA and an interior design project in a hotel in the Philippines $[17,69]$. On a smaller scale, Marco Ferreri produced a cabin printed as a single piece [40], and the MX3D office, also from the Netherlands, worked on projects for printing concrete and steel footbridges [1,14]. Other examples of 3D-printed elements executed by different organizations are summarized in Table 6.

Table 6. Examples of 3D-printed elements worldwide.

\begin{tabular}{cccc}
\hline Element & Description & Data & References \\
\hline Wall & $\begin{array}{c}\text { Double wall with an internal } \\
\text { structure }\end{array}$ & $\begin{array}{c}\text { Height: } 1.8 \text { m; by University of } \\
\text { Southern California, USA }\end{array}$ & {$[17,19,37,57]$} \\
\hline Bench & Free-form bench & $\begin{array}{c}2 \times 0.9 \times 0.8 \text { m; by the University } \\
\text { of Loughborough, UK }\end{array}$ & By Win Sun, China \\
\hline Rebar wall & $\begin{array}{c}\text { Wall with steel bars } \\
\text { reinforcement }\end{array}$ & [80,81] & {$[38,74]$} \\
\hline Truss with reinforcement & $\begin{array}{c}\text { Truss built with components } \\
\text { and steel reinforcement }\end{array}$ & \\
\hline
\end{tabular}


Table 6. Cont.

\begin{tabular}{cccc}
\hline Element & Description & Data & References \\
\hline Concrete wall & Rebar wall & $\begin{array}{c}\text { Height: 0.6 m; length 1.52 m; by } \\
\text { Khoshnevis }\end{array}$ & {$[41,58,82]$} \\
\hline Democrite & $\begin{array}{c}\text { Structural frame for a wall or } \\
\text { partition }\end{array}$ & By James Gardiner & [69,74] \\
\hline Curved wall & Double-curved slab component & $\begin{array}{c}\text { By the University of } \\
\text { Loughborough, UK }\end{array}$ & Wall built with round \\
Acoustic damping wall & $\begin{array}{c}\text { Components to optimize } \\
\text { acoustic behavior }\end{array}$ & $0.3 \times 0.65 \times 0.65$ m; by Gosselin & {$[40]$} \\
\hline
\end{tabular}

While an extensive variety of 3D-printed construction applications have been proposed by researchers, they have scarcely been verified beyond examples $[58,79,83]$. However, studies that show 3D-printed elements frequently analyze aspects such as execution speed, control, and diversity of shapes $[64,81,84]$. An emphasis on the execution of walls and single-family houses of one floor, as well as simple pavilions with novel building shapes, has also been revealed $[1,17,19,20,37,50,61,64,76,77]$. However, the means for reaching massive production for market purposes remain unexplored.

Furthermore, 3DPC applications show a relevant dispersion regarding the attributes and size of 3D-printed elements, without consolidating any specific repertoire or aspect, which reveals the emerging situation of this technology $[9,37,56,62,63]$. The size of elements and their complexity require significant resources, research, and development, and it is inversely proportional to the magnitude of production. Some examples of complex 3D-printed elements are shown in Table 7.

Table 7. Examples of 3DPC applications.

\begin{tabular}{|c|c|c|c|c|c|}
\hline & Furniture & Sculpture & Component & Wall & Building \\
\hline \multicolumn{6}{|l|}{ Shapes } \\
\hline \multicolumn{6}{|l|}{ Applications } \\
\hline & $\begin{array}{l}\text { Wonder Bench, } \\
\text { University of } \\
\text { Loughborough, UK }\end{array}$ & $\begin{array}{c}\text { Radiolaria, Enrico } \\
\text { Dini, D-Shape- } \\
\text { Monolite }\end{array}$ & $\begin{array}{c}\text { A Panel horizontally } \\
\text { printed. TU Delft, } \\
\text { Netherlands }\end{array}$ & $\begin{array}{c}\text { Double wall, } \\
\text { Gosselin, France }\end{array}$ & $\begin{array}{l}\text { Full Printed } \\
\text { House, Italy }\end{array}$ \\
\hline References & Courtesy of [22] & Courtesy of [22] & Courtesy of [81] & Courtesy of [81] & Courtesy of [85] \\
\hline
\end{tabular}

\section{Building Systems}

As shown before, an extensive variety of approaches can be found among the examples of AM applications in construction [1,14,17,22,25,40,49,60,69-74,82], with elements or complete buildings usually based on walls composed of horizontal cords made with cementitious mixtures, following circular or rectangular-extruded sections, which overlay on the vertical face, whether single or double.

Two main strategies have been identified regarding construction systems: mass and reinforced concrete. Mass concrete walls (see Figure 5, upper row) are mainly expected to resist compression efforts and therefore are enabled for dividing spaces and low buildings, 
in areas with reduced natural risks [80,83]. These consist of superimposed cords, occasionally forming curves [17,36] and parallel lines [84], being separated with a cavity [81] or internal diagonals, and sometimes filled with the same mixture or another material $[76,86]$. Generally, the wall's thickness is extended, apparently to obtain more lateral stability and thermal or acoustic insulation, although the separation and width attributes are not always specified, which may also be due to the reduction of material for exhibition [87,88]. In some cases, there are fastenings to the floor, the insertion of technical services, lintels, beams, windows, doors, or coverings $[17,39,41,77]$. However, no general strategies for adaptability or even compliance with regular building standards have been recognized.

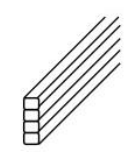

Simple

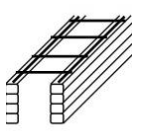

Horinzontal mesh

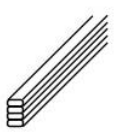

Width

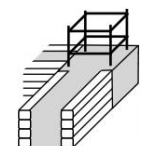

Reinforcement

Pillar

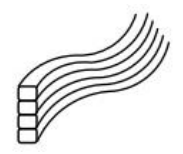

Curved

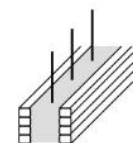

Reinforcement

Filler

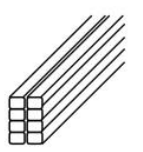

Parallel

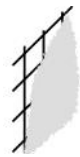

Projection

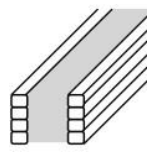

Filling

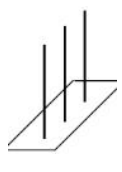

Printing

Bars

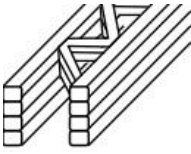

Crosslinked

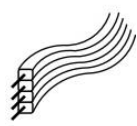

String with

filament

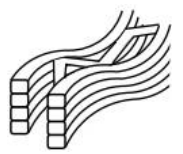

Curved

crosslinked

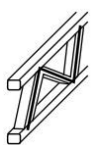

Lateral

Reinforcement

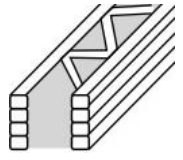

Crosslinked

filler

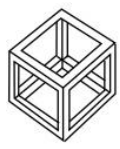

Spatial

Structure

Figure 5. 3D-printed mass and reinforced concrete approaches $[40,56,76,80,83,86,87,89]$.

The second strategy, which considers steel reinforcements to support greater structural efforts (see Figure 5, lower row) allows the execution of elements with a higher performance and greater buildings, as some specific initiatives have pointed out. One example is the use of horizontal meshes or ladders, installed every $500 \mathrm{~mm}$, with a wall thickness of $20 \mathrm{~cm}$ and height of up to $4.6 \mathrm{~m}$, reaching a resistance of $20 \mathrm{MPa}$ and including pillars in the corners or joints [88]. Furthermore, walls filled with concrete with vertical reinforcing bars of $12.7 \mathrm{~mm}$ diameter, with a maximum distance of $60.96 \mathrm{~cm}$ [87], or a projection of mixtures on steel meshes, generating a shell-type structure $3 \mathrm{~cm}$ thick [86], have been printed. There are cases where reinforcing bars have been printed with a diameter of $8 \mathrm{~mm}$, manufactured with an arc welding system [81], and a bicycle bridge printed with internal metal filament beads that will support a surface load of $5 \mathrm{kN} / \mathrm{m}^{2}$ [56]. Besides this, examples of cross-linked beams made with sections or modules that include a lateral steel bar reinforcement [74] or that have them incorporated into the final element [38] can be found.

Regarding roofs, they are traditionally executed as concrete slabs on flat formwork or wooden structures. Some specific initiatives have experimented with the printing of horizontal slabs [86] or vaulted roofs [90]. The Chinese company Winsun has disseminated images of some printed constructions made of sections (i.e., walls, floors, and roofs in one piece), which are assembled on-site, without specifying reinforcements or technical details.

It is possible to recognize a relevant evolution of the construction systems in videos and dissemination actions by western companies that have carried out more than one printed building (see Figure 6). These constructions maintain their strategy based on parallel cord-based hollow walls, with sections presenting reinforcement at the ends with a double cord or rectangle and a straight, diagonal, or lateral grid, apparently to ensure stability during execution. Thermal or acoustic performance are considered independently, as well as higher resistance capacities, which evidence progress in the modular strategies of execution, according to the amount of materials and location of equipment.

The geometric size of the building elements executed in the reviewed examples also shows a progressive consolidation, considering outstanding amplitudes, as shown in Table 8. Greater magnitudes of thickness, curvature, or reinforcement allow increasing of 
the dimensions of sections both in length and height. This increases their resistant capacities, although it also requires greater material consumption and equipment. Furthermore, making their execution more complex decreases the repeatability of printed elements. Therefore, it seems pertinent to focus on the development of construction systems in smaller magnitudes in order to gain better control of the general process.

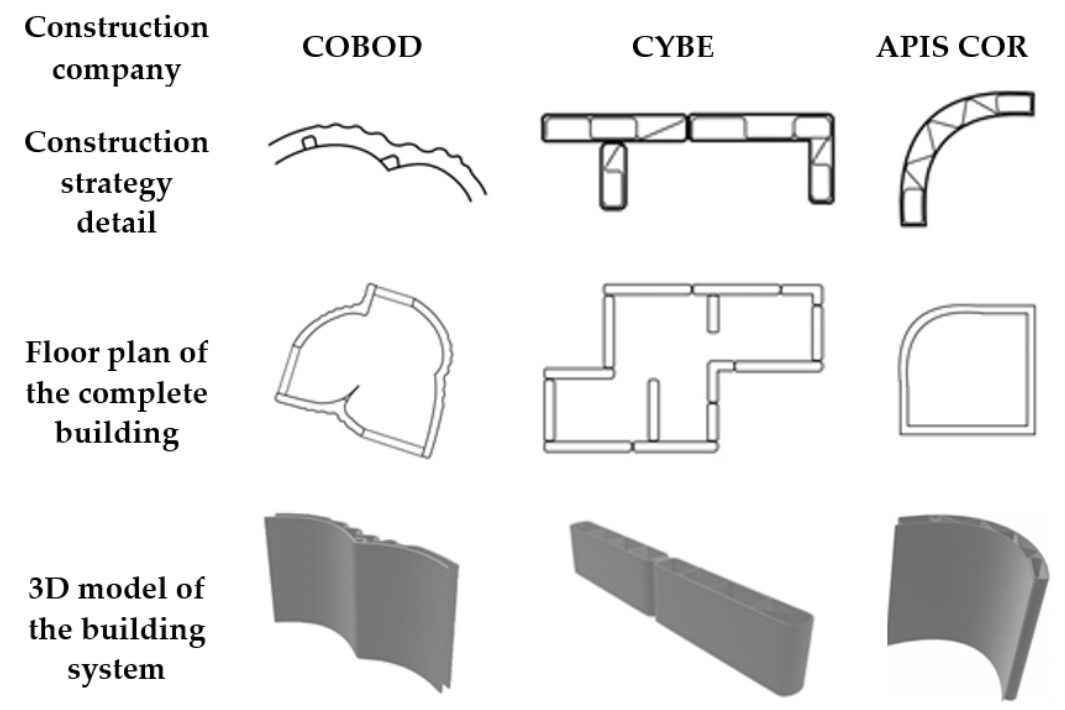

Figure 6. Details, plans, and 3D models of advanced 3D-printed wall strategies by several experienced construction companies.

Table 8. Dimensions of 3D-printed building elements.

\begin{tabular}{cccc}
\hline Dimension & Minimum $\mathbf{( c m )}$ & Maximum $\mathbf{( c m )}$ & Mean $\mathbf{( c m )}$ \\
\hline Cord width & 2 & 15 & 4 \\
Cord height & 1.5 & 5 & 2.5 \\
Wall thickness & 10 & 50 & 20 \\
Section length & 40 & 600 & 200 \\
Wall height & 200 & 300 & 240 \\
Crosslinked & 30 & 80 & 45 \\
\hline
\end{tabular}

Most of the executed buildings were based on the use of prefabricated systems that printed components on-site or off-site. In these examples, the material used varied from plain cement to cement with aggregates such as fiberglass, plastic fiber, and even construction waste [14,40]. Additionally, some developments have been identified that used 3D-printed formwork made with concrete or other materials to optimize the reinforced concrete construction process. Among these cases, the "Mesh Mold" developed by ETH stands out. It is made of plastic or metal filaments with different shapes, and it is built with robots to subsequently pour or project concrete so that the mesh can work as a reinforcement for the printed element $[69,70]$.

Another important factor for the construction strategy is the size of the printing system, which constrains the dimensions of the elements to be built and the capacity to print a complete building or to be executed by parts. Besides this, according to [91], printing speed influences the mechanical resistance of the printed elements, which would imply that the construction of smaller pieces and their assembly may be the most optimal method. Concerning the mechanical characteristics of walls, it is mentioned in the paper [73] that a compressive strength of $68.9 \mathrm{MPa}$ for a wall of $1.8 \mathrm{~m}$ height, while [88] established resistances between 19.1 $\mathrm{MPa}$ and $24.1 \mathrm{MPa}$, obtained through tests with samples of $150 \times 150 \times 150 \mathrm{~mm}$ and specified that the printed concrete was 2 to $4 \mathrm{MPa}$ weaker the traditional concrete. 
Regarding small printed elements, one of the most recurrent examples disseminated is the "Wonder Bench", performed by Loughborough University in the United Kingdom. The method used has been promoted as concrete printing. The bench has a curved shape with $2 \times 0.9 \mathrm{~m}$ and $0.8 \mathrm{~m}$ height, composed of 128 layers of printed concrete, complemented with steel reinforcement bars.

\section{Management}

The management of the manufacturing and supply chain has enabled the 3D-printing production processes. In this sense, an efficient and flexible control can improve the quality of construction of 3D-printed buildings [4,82]. The additive manufacturing management process considers the robotic platform, a power distribution substation, the design software, and the print nozzle. The final quality product with pre-established design features is obtained by correctly synchronizing the devices involved in the 3D-printing process. Figure 7 shows an overview of the computer-aided design (CAD) software, programming software, robotic platforms, and nozzles used in the construction process.

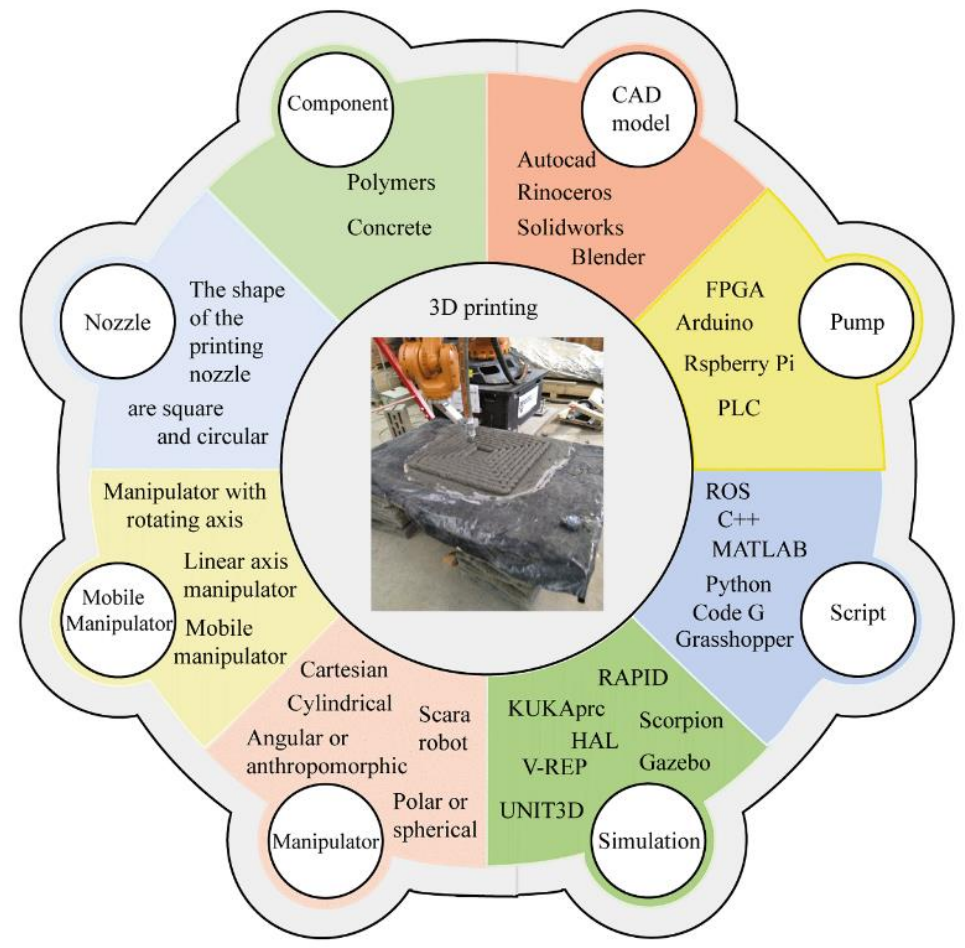

Figure 7. Printing diagram performed by a robotic system.

\subsection{Programming}

Pre-planning methods within CAD software are standard practice in the architectural and construction industries. CAD models are a digital representation of architectural design. Furthermore, these models improve design productivity and construction management with the new Building Information Modeling (BIM) approach. Recent research indicates the use of commercial design programs, such as AutoCAD, Revit, and/or Rhinoceros. CAD and BIM programs cover different degrees of detail ranging from a simple geometric model to a complex model $[36,71,92]$.

Usually, the CAD/BIM model is converted into parametric data that enable full control of the 3D-printing system [7]. The software that receives the model and communicates with the hardware can be HAL, KUKAprc, and/or Scorpion. These programs allow the transfer of information from the 3D model to the microcontrollers (Arduino, ATMEGA 164P, and PIC) $[92,93]$. There are some simulation programs to avoid damaging the real hardware (i.e., robots), such as V-REP, Gazebo, and UNIT3D, that allow testing of the monitoring, planning, and control algorithms of a robotic system for the 3D-printing process. 
The 3D model is generated by the CAD/BIM software, which is converted to G-code so that the robot can execute the instructions. This step provides parameters, including the size and height of the element to be printed and the robot's control actions. However, this first step is pre-processing, which is why it runs off-line. The main disadvantage of using pre-processed data is that they do not allow online control of the process. An alternative to CAD/BIM models consists of using programming languages such as MATLAB, ROS, Python, and C++ [94]. These tools enable a close integration between architectural design, the manufacturing process, and robot control.

The devices that control the material supply can be FPGA, PLC, Arduino, and RaspberryPi and allow for the operation of the pump with the correct synchronization of the construction process [95]. The pump supplies material through a hose connected to a nozzle located on the end-effector of the robot. The software and hardware tools aim to improve the construction process. This objective is achieved by considering the digital aspect of the tasks, understanding the operation and programming of robotic systems.

\subsection{Print Nozzle}

Automated construction processes require specific nozzles in shape and size. The selection of the nozzle type depends on the construction materials and the 3D-printed element's complexity [96]. Furthermore, the diameter of the nozzle directly affects the velocity and determines the height of the printed layer. Table 9 presents several types of nozzles used in the construction industry.

The YA-WA system uses an automatic computer-controlled manipulator, together with a mobile rail device to print a wall. In this work, the nozzle first prints a thin layer of $0.1-0.3 \mathrm{~cm}$ thickness. The next layer is approximately $1.5 \mathrm{~cm}$, while the last layer is of $0.7 \mathrm{~cm}$ thickness. The results from this work present the printing of a complete wall with a lower outlay on labor, materials, and equipment operation [97]. In large-scale 3Dprinting applications, the extruder can measure $0.3 \times 0.3 \times 2 \mathrm{~m}$, with layer thicknesses between 1 and $7 \mathrm{~mm}, 6-30 \mathrm{~mm}$ in width, printed at a speed between 0.05 and $1 \mathrm{~m} / \mathrm{s}$. Some 3D-printing experiments used a $25 \mathrm{~mm}$ diameter circular nozzle; however, the results presented a stacking problem [98]. Another study, where the nozzle size was $40 \times 10 \mathrm{~mm}$, concluded that $3 \mathrm{D}$ printing requires the printing orientation to remain tangent to the tool path [17].

Architectural design can involve complex geometries, which require a high level of detail. AM technology aims to form a solid structure through layer-by-layer printing. The adhesion between layers determines the stability and avoids the collapse of the structure during the printing process.

Table 9. Concrete 3D-printing nozzle design.

\begin{tabular}{|c|c|c|c|}
\hline Nozzle Type & & Nozzle Type & \\
\hline & $\begin{array}{l}\text { Nozzle linked to a robotic system } \\
\text { that moves on a rail [97]. }\end{array}$ & & $\begin{array}{l}\text { Nozzle with a helical system for } \\
\text { injecting the material [99]. }\end{array}$ \\
\hline & $\begin{array}{l}\text { Circular nozzle operated by a } \\
\text { gantry system [98]. }\end{array}$ & & $\begin{array}{l}\text { Multi-nozzle system allowing } \\
\text { different impression materials } \\
\text { to be mixed }[60,100] \text {. }\end{array}$ \\
\hline
\end{tabular}


Table 9. Cont.



Furthermore, the quality of the final product varies with the shape of the printing nozzle. Several studies have analyzed the shape of nozzle extruders for a better surface finish. Circular, ellipse, square, and rectangular nozzles have been studied [100]. For example, the 3D-printing profile created with a square extruder is better compared to an ellipse extruder [65]. The use of square extruders allows a quick and easy construction process. An alternative strategy to improve surface printing is to use a nozzle with side trowels [65]. Furthermore, some applications use multiple nozzle orifices to deposit material uniformly [60]. The features considered when designing a nozzle are a high level of automation, a high level of modularity, minimum weight, and easy cleaning [101]. Moreover, the design of the printing nozzle has to be easily adaptable to mechanical structures such as robotic arms, cranes or gantries [105].

\subsection{Short Description of Path Optimization Techniques in 3D-Printing Applications}

The advantages of 3D-printing technology include the construction of complex shapes and non-standard geometries. In [106], the authors show that printing speed is a function of the size and geometric complexity of the construction elements. The quality and efficiency of the final product depend on the printing direction [107-109]. Trajectory optimization techniques can improve the geometric execution of 3D printing $[110,111]$. The main issues are present in complex shapes with sharp corners and non-uniform space [112]. In the construction process, interior filling and linking sequences affect path planning. The strategy to reduce these problems uses two printing patterns: parallel direction paths and parallel contour paths [113]. Furthermore, to improve printing path efficiency, several 
filling patterns methods have been developed, such as Fermta spirals [114] and other alternatives, such as deposition angle optimization and printing speed regulation [115]. Figure 8 shows the printing direction of geometric profiles of different sizes, where length, width, and height are represented as $1, \mathrm{~h}$, and $a$, respectively, while distance between layers is represented as $\mathrm{d}$.
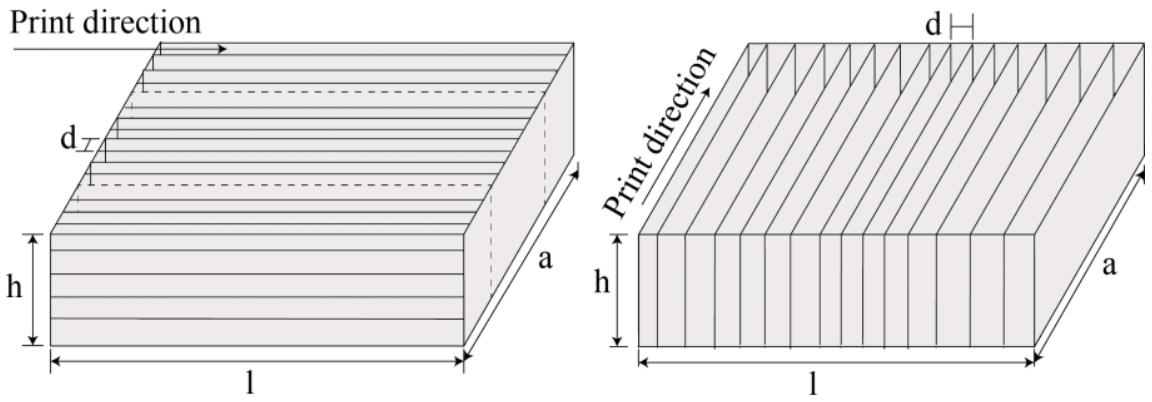

Figure 8. Example of construction geometries considering the direction of the printing nozzle and size of the profile.

The generation of a 3D-printed element involves controlling the printing speed and the uniform distribution of the extruded material. Some available studies generate trajectories based on lines and parables to build a 3D surface. Straight and parabolic segments allow controlling of these aspects through Bezier curves and a direction-parallel tool-path [116]. Furthermore, it is mentioned in the paper [117] that proposed a path planning with linear segments with parabolic blends (LSPBs) and minimum time path planning (MTT) at each printing transition. The aim was to minimize the printing time and to reach the desired path. Some applications use algorithms to solve path optimization systems, such as the Travel Salesman Problem algorithm (TSP), which aims to select the minimum distance between a pair of points [118].

Curved layered printing is reported in [119], where a practical B-spline based smoothing algorithm was used for removing sharp corners in the printing path. Furthermore, this method prevents the nozzle from vibrating and increases print quality. Route smoothing control was achieved through an intelligent neural network. The purpose of this method is to achieve higher efficiency than local and global smoothing algorithms [120]. The main problem of the toolpath smoothing algorithm is the consecutive corner smoothing of short linear segments [121]. Some works have used the path smoothing algorithm at the global and local level to improve smoothing and to maintain the original trajectory (i.e., path smoothing and feed rate planning for a robotic curved layer). Another example of path smoothing used an optimal feed rate with restrictions on rotation speed to avoid acceleration and jerk [122]. These smoothing methods present some problems with the position and orientation synchronization parameters of the robotic platforms [121]. For this reason, implementing a global geometric iteration method combined with local corner transition allows for generating a smooth path [123], while global approximation and global interpolation methods allow adjustment of the printing path position [124].

The incorporation of new geometric optimization methods has significantly improved the efficiency of 3D printing. Specifically, in fused deposition processes, the problem of print-head travel planning has been studied as a rural indirect postman problem. To improve this method, the authors used ant colony optimization, which has the advantage of significantly accelerating the optimization and printing process [125]. The rural indirect postman problem solves the unnecessary motion of the nozzle, while the computationally efficient heuristic search algorithm reduces printing time between layer transitions [126]. Another technique for optimizing the trajectory is Directed Energy Deposition (DED). DED improves geometric accuracy through redundancy in the rotation of the axis of each joint to improve printing by layers of a constrained trajectory [127]. Table 10 shows some of the models obtained by these methods. 
Table 10. Examples of 3D-printed curved elements.

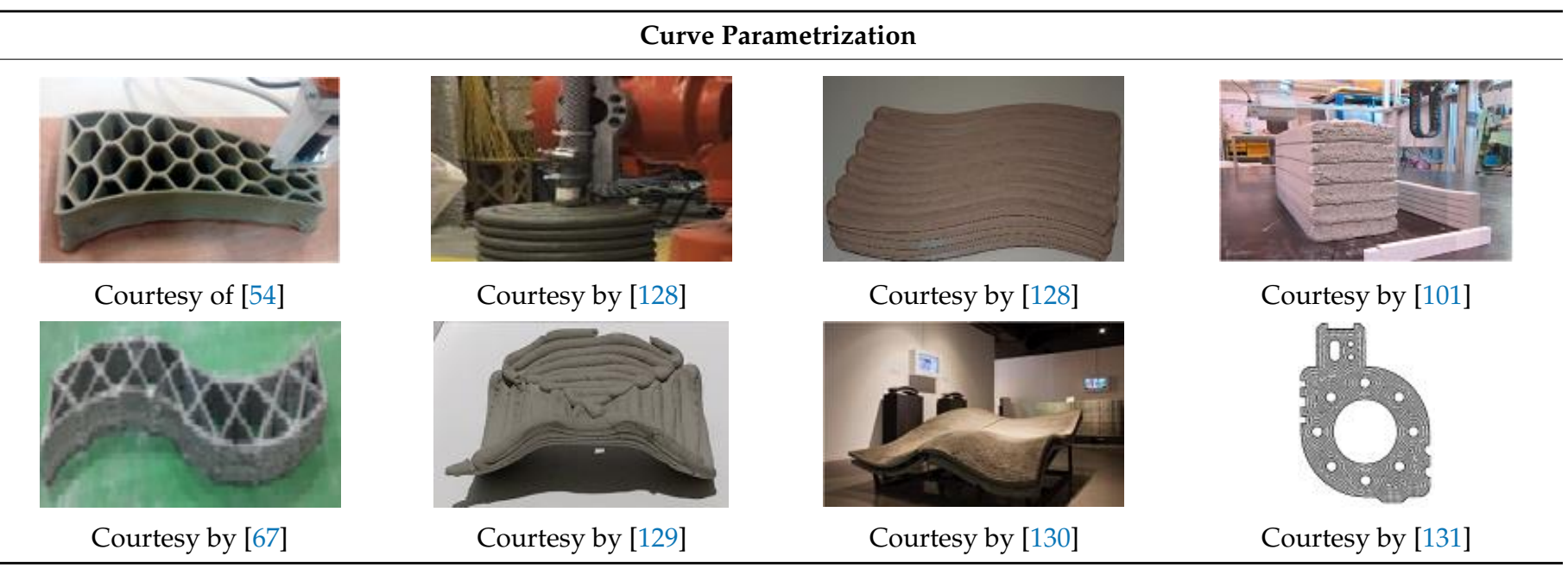

\subsection{Pump}

Another important component in an automated building construction system is the automated unit for material preparation and pushing (i.e., pump). This device allows blending supplies according to the mixture design and the printing size. The development of each project in the construction industry requires different models of mixer pumps [132,133]. The functions of the automated unit for material preparation are to blend and transport the mixture through the pipeline connected to the end-effector [88]. Reiter et al. [132] described an automated unit with two silos to store and feed cementitious powders to the continuous mixer. Another model consists of two peristaltic pumps, one for the accelerating agent and one for the premix [7]. In other cases, the material distribution is carried out using a pressurized canister, where the material flows through the inflatable bladder located in the end-effector [134].

Pumps have an essential role in automated 3D-printed construction [132]. The purpose of the pump is to deliver the material to a specific position autonomously and precisely [135]. Figure 9 shows the previous process of the material that will reach the pump. It starts with a production phase, then additives are added to the mixture, and subsequently, it goes through a station where the mixture dries. In the next step, the blend goes through a process where it is kept wet. In the pumping phase, the mixture obtained in the previous step enters the pump, which is in charge of distributing it through a hose to the extruder during the printing phase [132].

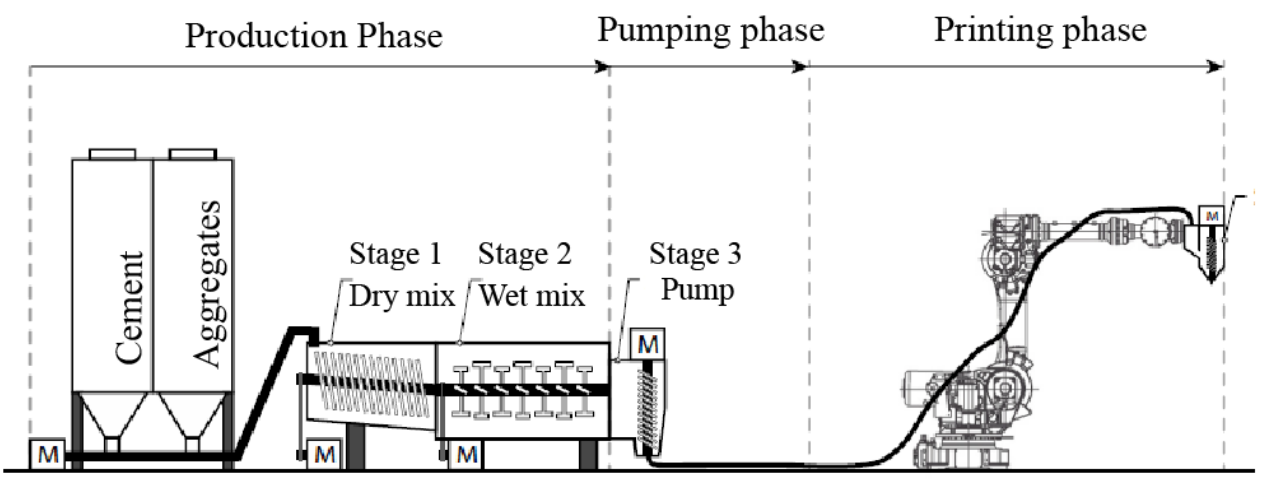

Figure 9. Stages of material supply in a 3D-printing process using robots (courtesy of [132]). 


\section{Advantages}

As determined by Anjum et al. [136] through a survey to stakeholders of the Indian construction sector, numerous advantages are expected to stem from the application of 3DPC instead of traditional construction techniques. While some authors [17,137] prefer to focus on detecting unsolved challenges and proposing solutions, the vast majority of studies on this topic mention some of the advantages of this new technology $[65,77,138]$; however, only a few actually analyze them. In this section, a review of the advances made in their exploration and quantification is presented in order to identify those that have been more frequently approached and those avenues maybe needing further attention in forthcoming research. This is expected to provide insights on the Technology Readiness Level (TRL) of 3DPC in terms of the study of its advantages.

Jagoda et al. [138] provided an overview of several advantages: the unnecessary formwork, efficiency of the process, reduced labor demand, and cost reduction. Concretely, the latter resulted in $50 \%$ higher costs than conventional construction techniques due to the special printing material being far more expensive than conventional concrete. Kreiger et al. [87] performed a cost comparison analysis of 3DPC to a conventional concrete masonry unit (CMU) and cast-in-place concrete construction. The results showed that materials and machinery costs were higher for 3DPC case studies, since the printing material is still more expensive than more widespread concrete or CMU, and a high cost was assumed for the printing machinery. However, labor costs were $40-55 \%$ lower than those of traditional construction, which translated into a 10-37\% reduction of the total cost with respect to traditional techniques. However, cost analysis is usually made as part of multi-objective analyses, such as that by Alwi et al. [139], who performed a general review and analysis of economic and logistic aspects of 3DPC. To that end, they studied a hypothetical construction company focused on modulation of buildings to fabricate the various parts at a plant and assemble them on-site. Another example is the study by García de Soto et al. [140], who carried out a comprehensive productivity analysis focused on time and cost requirements for a straight and a curved wall built using conventional construction and robotic systems. While robotic fabrication did not show significant economic advantages, mainly due to the currently considerable cost of equipment, this is expected to change with further insertion of this technology into the market. Regarding productivity, conventional construction outperformed robotic fabrication when working with straight walls. However, when working on more complex shapes, the latter offered a clear advantage.

Bosscher et al. [141] combined a cost and productivity analysis of contour crafting with a cable-suspended robot, compared to traditional techniques, to build a concrete wall and established that both methods would have a similar cost $\left(\sim 40 \mathrm{US} \$ / \mathrm{m}^{3}\right)$ without considering savings related to accidents, safety training, and labor. Moreover, contour crafting would produce $98 \mathrm{~m}^{3} /$ day, only needing one foreman, while conventional techniques would produce $77 \mathrm{~m}^{3}$ /day with the participation of one foreman, four laborers, and one cement finisher, with this productivity being $27 \%$ greater. Martínez-Rocamora et al. [142] performed a massive analysis of enclosure designs through a parametric automated generation algorithm. The analysis focused on cost, time, and material consumption as managed resources to be reduced in architectural projects, thus considerably accelerating the analysis process carried out by designers in early stages. Finally, Allouzi et al. [143] carried out a material cost analysis of building a project in Jordan with conventional techniques and using contour crafting. However, labor costs were not considered in their study, and therefore, its results do not offer all the necessary information to cover this advantage, since reduction in labor needs is a key aspect.

While Wolfs mentioned numerous advantages of 3DPC [144], he focused on evaluating printing speed because of its influence on both the bond strength between printed layers and the overall strength development of printed concrete. In his study, he found that at very high print speeds, the bond strength does not reduce significantly, while establishing a maximum print speed to prevent fresh layers to arrive too soon on the old ones was not considered. On the other hand, Diggs-McGee et al. [145] presented an interesting 
approach to measure time in 3DPC, with three different measures: print time, elapsed time, and construction time. The former refers to the time the printing machine is extruding material. The second considers the print time plus delays during the printing process for set-up, calibration, etc. Construction time adds to the previous ones the breaks in order to compute the actual number of days to print a certain object, item, or structure. Barnett and Gosselin [98] calculated the speed and accuracy in positioning of a cable-suspended robot for large-scale 3D printing, applying optimization in a kinematics and dynamics analysis.

Krimi et al. [79] carried out an extensive analysis of design flexibility and building rates using 3DPC. This analysis allowed for quantifying, in terms of economic cost, the advantage of not needing formwork when printing walls with singular forms, as well as the significant reduction of the time required to build a certain structure, which can be 1.7 times faster than prefabrication and four times faster than cast-in-place concrete. Carneau et al. [146] explored the geometries and construction processes of three traditional masonry structures without formwork in order to analyze the feasibility and stability of their equivalents using 3D-printed construction. In their work, they proposed interesting modifications to the 3D-printing process, such as bending the printed layers downwards near the arches, thus obtaining non-planar paths that must be compensated for afterwards. On the other hand, structures such as domes, which progressively reduce the layers' length and therefore their printing time, posed difficulties related to the setting time of previous layers, and thus, the stability of the final layers was compromised.

Sustainability has also been explored on several occasions. De Schutter et al. [78] provided an overview of the economic and environmental potential of 3DPC based on the possibilities of decreasing labor needs and performing structural optimization, as well as functional hybridization. The latter was defined by the authors as a strategy to use complex forms to achieve multi-functionality. Agustí-Juan and Habert [147] performed a comprehensive environmental analysis of three case studies built using 3DPC and provided design guidelines to achieve more sustainable projects. They concluded that the environmental impact caused by the robotic fabrication processes was negligible compared with materials production while allowing the integration of additional functions in the structure, such as a self-shading effect or finishing and acoustic roof solutions. Digital fabrication also allowed the optimization of material use, although the selection of materials should consider the balance between the energy reduction in the use phase of the building and the waste generation in the end-of-life phase.

Pan et al. [29] developed a framework of indicators for assessing the sustainability of construction automation and robotics (CAR) instead of traditional techniques. In that framework, concepts such as material use optimization, waste minimization, energy consumption, air pollution, noise emission or water use, and pollution are measured as contributing factors to the environmental impact of CAR. Economic, social, and technological performance indicators are included as well to configure a total of 75 different indicators, through which the sustainability of CAR projects can be evaluated. Regarding energy efficiency, Gomaa et al. [148] performed a thermal performance analysis of several mixtures of 3D-printed cob, reaching conductivities of 0.32 to $0.48 \mathrm{~W} / \mathrm{mK}$, with densities of 1397 to $1780 \mathrm{~kg} / \mathrm{m}^{3}$. These results were comparable to those of the hand-made counterparts $(0.25-0.84 \mathrm{~W} / \mathrm{mK})$, thus revealing a promising future of 3DPC with non-cementitious materials.

Free-form design is usually studied along with mass customization possibilities. Ibrahim [149] analyzed the influence of 3DPC technologies in architectural forms, finally stating that the constructions produced for the moment are just traditional forms produced with a new technology instead of the endless possibilities envisioned by 3DPC. Al Jassmi et al. [71] reviewed the state-of-the-art of free-form design, which, according to them, creates a new paradigm change in the field of building design, and concluded that future research should focus on performance improvement of 3DPC structures. Fischer and Herr [150] developed an online mass customization platform based on 3DPC technologies with Python, Rhinoceros, and Grasshopper, where alternative designs for pavilions were formed by successive vertical sections horizontally printed and subsequently turned on 
their side after concrete had hardened. In that platform, users were able to configure their designs, which were then subjected to an in-depth structural analysis.

Davtalab et al. [151] proposed a methodology for the automation of the construction process, starting with a BIM model, which was subsequently analyzed and sliced. After that, the sliced model was solved using a toolpath optimization strategy and then communicated with the robot to print the original design. On the other hand, Kontovourkis and Tryfonos [54] focused on automating small/medium and large-scale 3D clay printing tasks through the integration of parametric design and robotic additive manufacturing. This integration allowed them to automate toolpath planning and extrusion control to print an unconventional form defined by a digital model. Nadal et al. [152] presented a workflow for an integrated design-to-fabrication process using six-axis robotic arms, automatically relating virtual models with the fabrication itself, solving the necessary design refinements, and automating non-critical tasks. Their workflow bridges the gap between the different systems involved through software packages that act as interpreters to integrate 3D modeling platforms, machine interaction and setup, and fabrication.

In Appendix A, Table A1 shows the total number of articles mentioning or analyzing each of the identified advantages of 3DPC. Furthermore, the corresponding percentages over the 86 reviewed articles are presented. As can be seen, low cost, high speed, no formwork, free-form design, and sustainability are the most commonly mentioned advantages in articles on 3DPC. Mass customization is usually mentioned along with free-form design in articles focused on architectural design, while measurable advantages such as cost, speed, or sustainability are commonly mentioned and analyzed in engineering articles. Furthermore, despite the fact that they are usually mentioned in 3DPC articles, non-measurable advantages are not often analyzed. This is probably due to the novelty of this technology and the continuous advances and new systems that make some of its properties difficult to be defined in a form that keeps being valid for all the existing and future proposals. It is also worth mentioning that most of the analyses focused on measurable advantages that make it easier to compare to other studies. However, automation draws significant attention in 3DPC studies, with several authors proposing methodologies in order to standardize the steps to be followed in the use of this new technology.

In Figures 10 and 11, a clear trend can be identified in 3DPC research, with an increased number of articles from 2004 until now which usually mention advantages such as free-form design, mass customization, sustainability, high speed, or low cost. As mentioned before, these are also the most analyzed topics in recent articles, thus highlighting the need to study other advantages, such as precision or safety, through more rigorous analyses. In general, it can be considered that the advantages of 3DPC are widely mentioned in articles on this field but have scarce studies that support them with comprehensive analyses. In future research, these should be more thoroughly analyzed in order to better quantify them and to gain understanding on the benefits of using 3DPC instead of traditional construction techniques. 

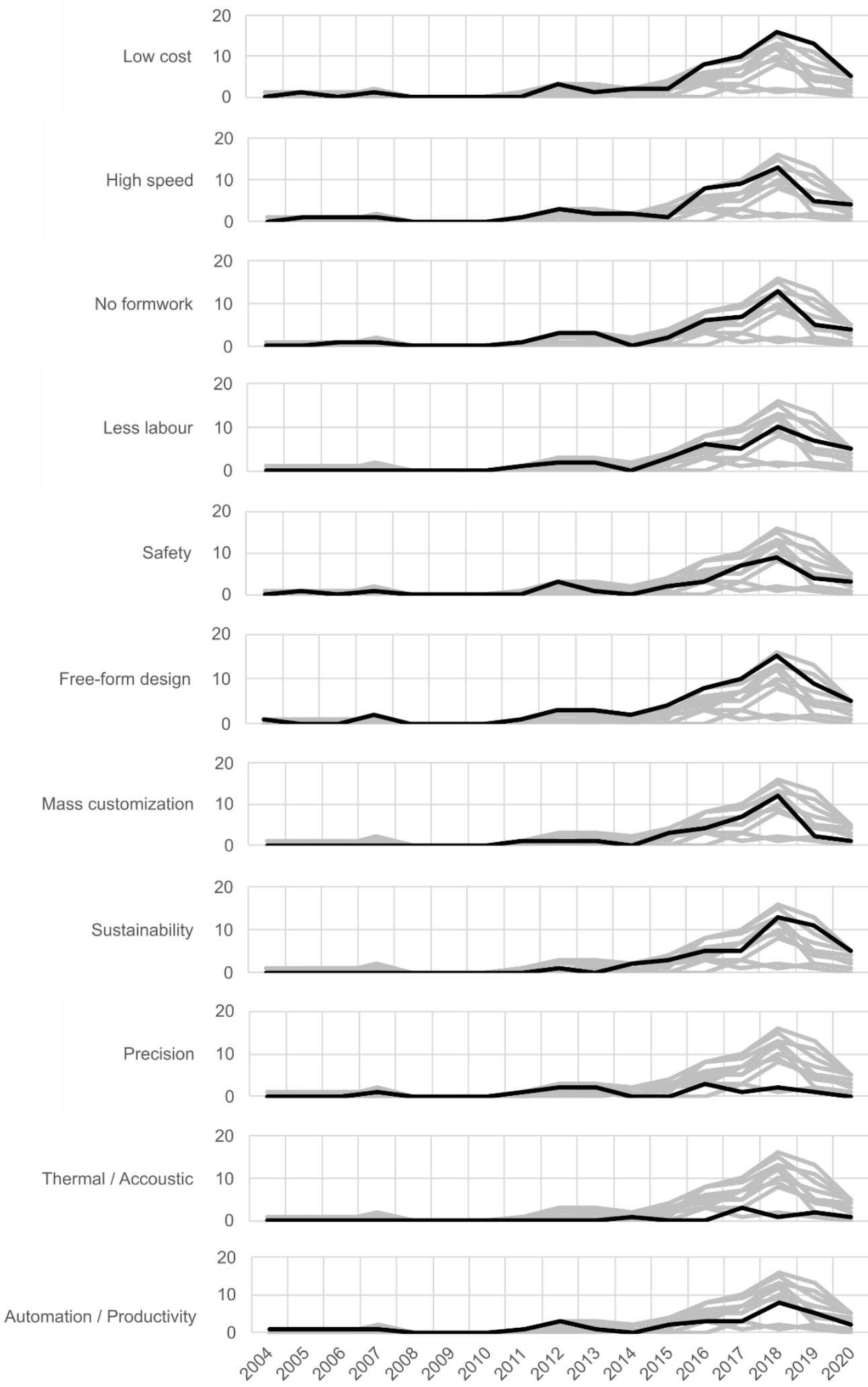

Figure 10. Mentions of 3DCP advantages in scientific literature over time. 

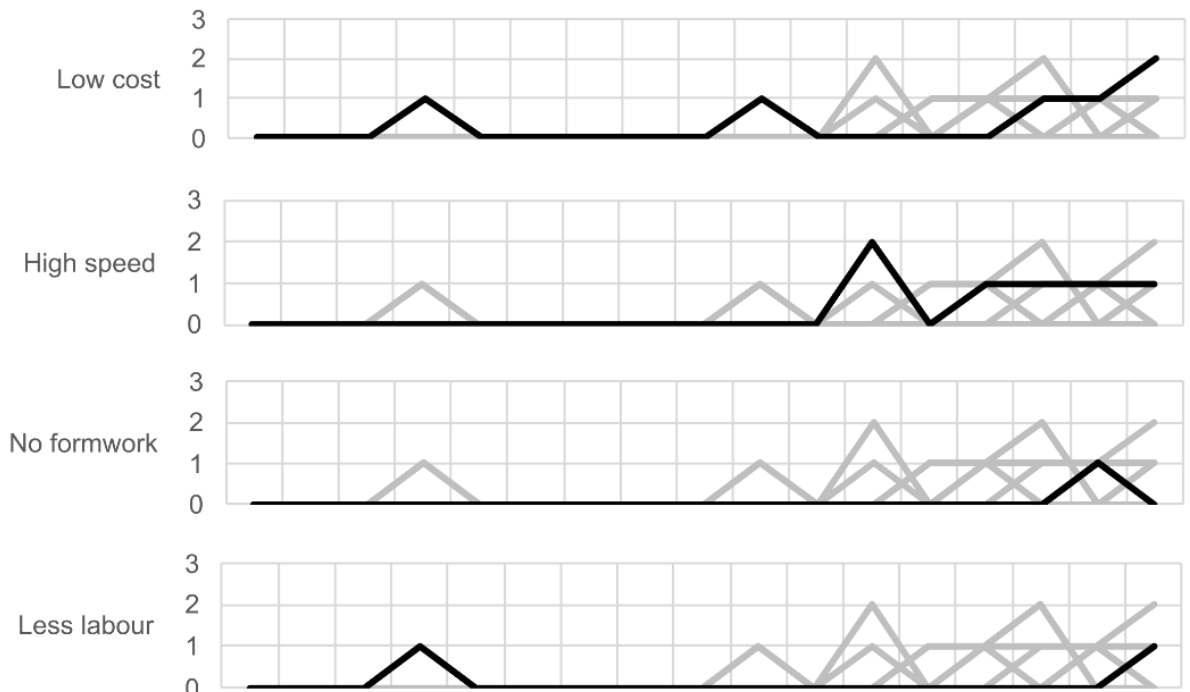

Safety
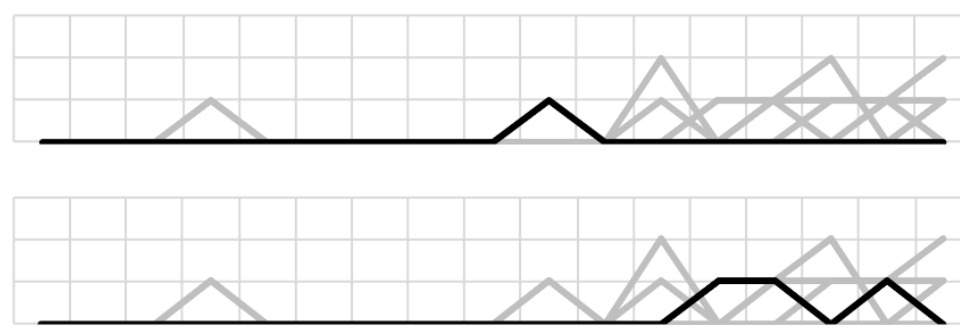

Mass customisation

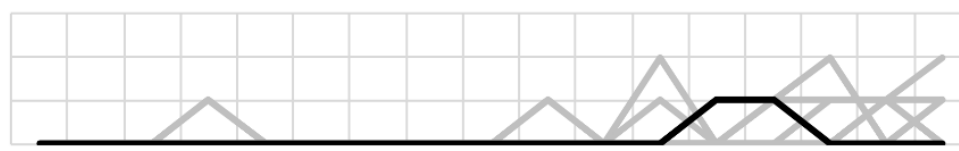

Sustainability

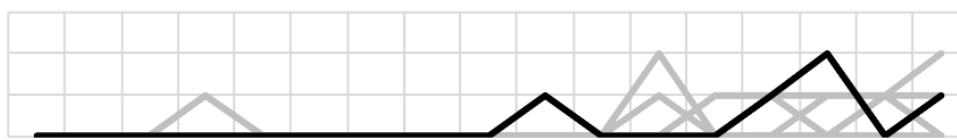

Precision

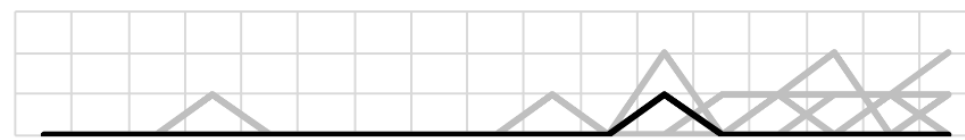

Thermal / Accoustic

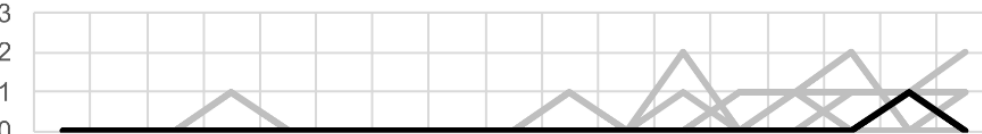

Automation / Productivity

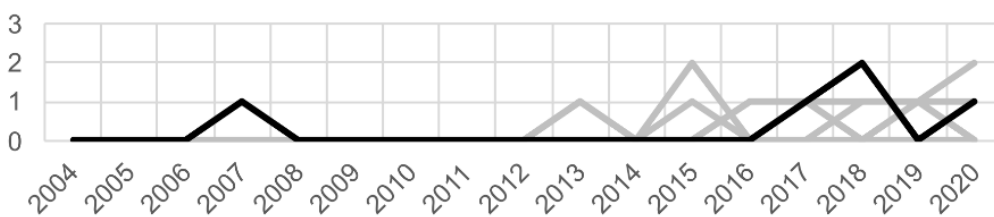

Figure 11. Analyses of 3DCP advantages in scientific literature over time.

\section{Conclusions and Future Recommendations}

3D-printing technology has emerged as a promising method to address the challenges of the construction sector, as well as to open new avenues related to the research of materials and building designs. Different parameters related to the development of cementitious mixtures have been analyzed and compared. To date, attributes and means of testing have 
been consolidated, with compounds dependent on local conditions, usually with a high proportion of cement that implies high costs and carbon emissions and/or a difficulty of balancing these aspects. The properties of printing mixtures recognize the main challenges to control opening time to reduce the environmental footprint and to improve buildability. There is also interest in experimenting with fibers that improve performance and with alternative materials based on polymers or clay.

The equipment and management systems used in 3D-printed construction show a variety of techniques and diverse combinations of features and functions. For example, gantries, robotic arms, and mobile manipulators can be controlled through CAD/BIM design and parametric software to extrude cementitious materials. The design parameters are related to the size of the printed elements, the capacity of the robotic platforms, and the labour force.,. Technological alternatives must define regular procedures and relationships to focus on production.

The 3D-printed construction works show applications oriented by both attributes and types of components, which express a broad but divergent development. Capacities focus on different operational properties or performances and elements of different sizes and uses. The progressive evaluation of attributes of some components will enhance the production and commercial development of this technology, which requires both experimental verifications and transfer projections that must be properly disseminated. Construction systems with 3D-printed elements also present a progressive consolidation of wall strategies and integration of services and structures to execute buildings.

The main novelty of this review on 3D-printed construction relies on the amplitude of the analyzed topics related to this new technology, including materials, technology, applications, and advantages, among others. A structured vision of the technological development is provided, oriented to its market projection. We have identified areas of research and development in building applications, such as optimization techniques for 3D-printing of curved and straight elements and the use of equipment with multiple degrees of freedom, that represent a significant challenge in the construction sector. For this reason, the comprehensive understanding of the current status of optimization techniques will enable researchers and practitioners to choose the best option to achieve efficient 3Dprinting of building elements. Furthermore, trajectory optimization allows for improved surface quality, less use of support structures, and improved isotropy. The link between the capabilities of 3D-printed construction techniques and the design of building elements allows for the effective application of this new technology.

Author Contributions: Conceptualization: All authors; The research was performed under the supervision of F.A.-C. Literature Review: All authors. Research Method: All authors; Drafting the article based on the results: R.G.-R., A.M.-R. and F.A.-C. Reviewed the paper F.A.-C., R.G.-A. and A.M.-R. All authors have read and agreed to the published version of the manuscript.

Funding: This research was funded by ANID (ex CONICYT) FONDECYT 1181015, the Advanced Center of Electrical and Electronic Engineering AC3E CONICYT FB008, DGIIP-UTFSM Chile, and the 6th Own Research and Knowledge Transfer Plan of the University of Seville (VI-PPIT US).

Institutional Review Board Statement: Not applicable.

Informed Consent Statement: Not applicable.

Data Availability Statement: Not applicable.

Acknowledgments: The authors would like to acknowledge FONDECYT 1181015, the Advanced Center of Electrical and Electronic Engineering AC3E ANID FB0008, DGIIP-UTFSM $\sim$ Chile, and the 6th Own Research and Knowledge Transfer Plan from the University of Seville (VI-PPIT US).

Conflicts of Interest: The authors declare that they have no known competing financial interests or personal relationships that could have appeared to influence the work reported in this paper. 


\section{Appendix A}

Table A1. References.

\begin{tabular}{|c|c|c|c|c|c|c|}
\hline \multirow{2}{*}{ Advantage } & \multicolumn{2}{|c|}{ Mentions } & \multicolumn{4}{|c|}{ Analyses } \\
\hline & Total & Percentage & Refs. & Total & Percentage & Refs. \\
\hline Low cost & 62 & $72 \%$ & $\begin{array}{c}{[1,22,24,36,49,54,59,61,62,70,71,73,78,79,83,84,88,102} \\
135,136,138,146,148-172]\end{array}$ & 6 & $7 \%$ & {$[87,139-143]$} \\
\hline High speed & 51 & $59 \%$ & $\begin{array}{c}{[1,18,22,36,40,49,54,59,62,70,73,80,81,83,84,88,102,130} \\
135,136,138,139,141,143,147,149-151,153,155- \\
160,162-166,169,172-179]\end{array}$ & 6 & $7 \%$ & {$[81,103,141,143,145]$} \\
\hline No formwork & 46 & $53 \%$ & $\begin{array}{c}{[1,16,22,33,37,59,61,62,70-72,74,77-} \\
80,83,130,135,138,139,141,145,147,149,151,152,156,157 \\
159,162,164,171-173,175,177-182]\end{array}$ & 1 & $1 \%$ & [42] \\
\hline Less labour & 41 & $48 \%$ & $\begin{array}{c}{[1,22,29,36,38,40,59,62,72,83,84,102,135,136,138,141,143} \\
153,155-157,160,162,163,167,168,171- \\
173,176,178,181,183]\end{array}$ & 2 & $2 \%$ & {$[141,142]$} \\
\hline Safety & 34 & $40 \%$ & $\begin{array}{c}{[1,22,29,36,38,40,59,62,72,83,84,102,135,136,138,141} \\
143,153,155-157,160,162,163,167- \\
169,171,173,175,176]\end{array}$ & 1 & $1 \%$ & [139] \\
\hline Free-form design & 63 & $73 \%$ & $\begin{array}{c}{[16,18,22,24,30,36,37,40,59,61,62,70-73,76,78,80-} \\
85,88,98,102,130,135,136,139,141,142,148,150,152,154, \\
156,157,159-162,164-166,168,171,172,176-185]\end{array}$ & 3 & $3 \%$ & {$[81,146,149]$} \\
\hline Mass customization & 32 & $37 \%$ & $\begin{array}{c}{[18,22,24,37,40,49,56,59,70-72,76-78,84,98,102,130} \\
136,142,147,149,152,165,178,179,181,183]\end{array}$ & 2 & $2 \%$ & {$[79,150]$} \\
\hline Sustainability & 45 & $52 \%$ & $\begin{array}{c}{[1,36,38,40,54,59,61,62,70-72,77,80,83-} \\
85,88,130,135,136,138,143,145,146,148,152,157,158 \\
160,161,163,165,167,169-173,175,176,178,180,181,183]\end{array}$ & 5 & $6 \%$ & {$[28,80,140,143,147]$} \\
\hline Precision & 13 & $15 \%$ & {$[19,38,62,140,142,148,157,160,162,176,179,182]$} & 1 & $1 \%$ & [98] \\
\hline Thermal/acoustic & 8 & $9 \%$ & {$[59,64,68,78,86,152,163,172]$} & 1 & $1 \%$ & [186] \\
\hline $\begin{array}{l}\text { Automation/Pro } \\
\text { ductivity }\end{array}$ & 32 & $37 \%$ & $\begin{array}{c}{[22,29,36-38,40,70,80,84,98,130,136,138,150,153-} \\
155,157,164,167,168,172-174,177,179,180,183-185]\end{array}$ & 5 & $6 \%$ & {$[55,141,142,151,152]$} \\
\hline
\end{tabular}

\section{References}

1. Bogue, R. What are the prospects for robots in the construction industry? Ind. Rob. 2018, 45, 1-6. [CrossRef]

2. Buchli, J.; Giftthaler, M.; Kumar, N.; Lussi, M.; Sandy, T.; Dörfler, K.; Hack, N. Digital in situ fabrication-Challenges and opportunities for robotic in situ fabrication in architecture, construction, and beyond. Cem. Concr. Res. 2018, 112, 66-75. [CrossRef]

3. Sasson, A.; Johnson, J.C. The 3D printing order: Variability, supercenters and supply chain reconfigurations. Int. J. Phys. Distrib. Logist. Manag. 2016, 46, 82-94. [CrossRef]

4. Chan, H.K.; Griffin, J.; Lim, J.J.; Zeng, F.; Chiu, A.S.F. The impact of 3D Printing Technology on the supply chain: Manufacturing and legal perspectives. Int. J. Prod. Econ. 2018, 205, 156-162. [CrossRef]

5. Tahmasebinia, F.; Niemelä, M.; Sepasgozar, S.M.E.; Lai, T.Y.; Su, W.; Reddy, K.R.; Shirowzhan, S.; Sepasgozar, S.; Marroquin, F.A. Three-dimensional printing using recycled high-density polyethylene: Technological challenges and future directions for construction. Buildings 2018, 8, 165. [CrossRef]

6. Sobotka, A.; Pacewicz, K. Mechanisation and automation technologies development in work at construction sites. IOP Conf. Ser. Mater. Sci. Eng. 2017, 251, 12046. [CrossRef]

7. Gosselin, C.; Duballet, R.; Roux, P.; Gaudillière, N.; Dirrenberger, J.; Morel, P. Large-scale 3D printing of ultra-high performance concrete-A new processing route for architects and builders. Mater. Des. 2016, 100, 102-109. [CrossRef]

8. Makul, N. Advanced smart concrete-A review of current progress, benefits and challenges. J. Clean. Prod. 2020, $274,122899$. [CrossRef]

9. El-Sayegh, S.; Romdhane, L.; Manjikian, S. A critical review of 3D printing in construction: Benefits, challenges, and risks. Arch. Civ. Mech. Eng. 2020, 20, 34. [CrossRef]

10. Labonnote, N.; Rønnquist, A.; Manum, B.; Rüther, P. Additive construction: State-of-the-art, challenges and opportunities. Autom. Constr. 2016, 72, 347-366. [CrossRef]

11. Jain, P.; Kuthe, A.M. Feasibility study of manufacturing using rapid prototyping: FDM approach. Procedia Eng. 2013, 63, 4-11. [CrossRef]

12. ASTM Standard. Standard Terminology for Additive Manufacturing Technologies; Astm International: West Conshohocken, PA, USA, 2012. 
13. Kosmatka, S.H.; Kerkhoff, B.; Panarese, W.C. Design and Control Design and Control of Concrete Mixtures, 17th ed.; Portland Cement Association: Portland, OR, USA, 2008; ISBN 0893122173.

14. Caron, J.F.; Demont, L.; Ducoulombier, N.; Mesnil, R. 3D printing of mortar with continuous fibres: Principle, properties and potential for application. Autom. Constr. 2021, 129, 103806. [CrossRef]

15. Bautista-Gutierrez, K.P.; Herrera-May, A.L.; Santamaría-López, J.M.; Honorato-Moreno, A.; Zamora-Castro, S.A. Recent progress in nanomaterials for modern concrete infrastructure: Advantages and challenges. Materials 2019, 12, 3548. [CrossRef]

16. Le, T.T.; Austin, S.A.; Lim, S.; Buswell, R.A.; Gibb, A.G.F.; Thorpe, T. Mix design and fresh properties for high-performance printing concrete. Mater. Struct. Constr. 2012, 45, 1221-1232. [CrossRef]

17. Bos, F.; Wolfs, R.; Ahmed, Z.; Salet, T. Additive manufacturing of concrete in construction: Potentials and challenges of 3D concrete printing. Virtual Phys. Prototyp. 2016, 11, 209-225. [CrossRef]

18. Kazemian, A.; Yuan, X.; Cochran, E.; Khoshnevis, B. Cementitious materials for construction-scale 3D printing: Laboratory testing of fresh printing mixture. Constr. Build. Mater. 2017, 145, 639-647. [CrossRef]

19. Lim, S.; Buswell, R.A.; Le, T.T.; Austin, S.A.; Gibb, A.G.F.; Thorpe, T. Developments in construction-scale additive manufacturing processes. Autom. Constr. 2012, 21, 262-268. [CrossRef]

20. Ma, G.; Li, Z.; Wang, L. Printable properties of cementitious material containing copper tailings for extrusion based 3D printing Constr. Build. Mater. 2018. [CrossRef]

21. Weng, Y.; Li, M.; Tan, M.J.; Qian, S. Design 3D printing cementitious materials via Fuller Thompson theory and Marson-Percy model. Constr. Build. Mater. 2018, 163, 600-610. [CrossRef]

22. Panda, B.; Mohamed, N.A.N.; Paul, S.C.; Singh, G.V.P.B.; Tan, M.J.; Šavija, B. The effect of material fresh properties and process parameters on buildability and interlayer adhesion of 3D printed concrete. Materials 2019, 12, 2149. [CrossRef]

23. Rubio, M.; Sonebi, M.; Amziane, S. Fresh and Rheological Properties of 3D Printing Bio-Cement-Based Materials. J. Civ. Eng. 2017, 35, 283-290.

24. Ma, G.; Wang, L. A critical review of preparation design and workability measurement of concrete material for largescale 3D printing. Front. Struct. Civ. Eng. 2018, 12, 382-400. [CrossRef]

25. Chen, Y.; Veer, F.; Copuroglu, O.; Schlangen, E. Feasibility of Using Low $\mathrm{CO}_{2}$ Concrete Alternatives in Extrusion-Based 3D Concrete Printing; Springer International Publishing: Berlin/Heidelberg, Germany, 2019; Volume 19, ISBN 9783319995199.

26. Antoni, M.; Rossen, J.; Martirena, F.; Scrivener, K. Cement substitution by a combination of metakaolin and limestone. Cem. Concr. Res. 2012, 42, 1579-1589. [CrossRef]

27. Lu, B.; Weng, Y.; Li, M.; Qian, Y.; Leong, K.F.; Tan, M.J.; Qian, S. A systematical review of 3D printable cementitious materials. Constr. Build. Mater. 2019, 207, 477-490. [CrossRef]

28. Pan, M.; Linner, T.; Pan, W.; Cheng, H.; Bock, T. A framework of indicators for assessing construction automation and robotics in the sustainability context. J. Clean. Prod. 2018, 182, 82-95. [CrossRef]

29. Hambach, M.; Volkmer, D. Properties of 3D-printed fiber-reinforced Portland cement paste. Cem. Concr. Compos. 2017, 79, 62-70. [CrossRef]

30. Bos, F.P.; Ahmed, Z.Y.; Jutinov, E.R.; Salet, T.A.M. Experimental exploration of metal cable as reinforcement in 3D printed concrete Materials 2017, 10, 1314. [CrossRef]

31. Wolfs, R.J.M.; Bos, F.P.; Salet, T.A.M. Early age mechanical behaviour of 3D printed concrete: Numerical modelling and experimental testing. Cem. Concr. Res. 2018, 106, 103-116. [CrossRef]

32. Craveiro, F.; Nazarian, S.; Bartolo, H.; Bartolo, P.J.; Pinto Duarte, J. An automated system for 3D printing functionally graded concrete-based materials. Addit. Manuf. 2020, 33, 155-173. [CrossRef]

33. Rane, K.; Strano, M. A comprehensive review of extrusion-based additive manufacturing processes for rapid production of metallic and ceramic parts. Adv. Manuf. 2019, 7, 155-173. [CrossRef]

34. Khoshnevis, B. Toward Total Automation of On-Site Construction-An Integrated Approach Based on Contour Crafting. In Proceedings of the 20th ISARC, Eindhoven, The Netherlands, 21-24 September 2003; pp. 61-66. [CrossRef]

35. $\mathrm{Wu}, \mathrm{X}$; Huang, Y. Adaptive fractional-order non-singular terminal sliding mode control based on fuzzy wavelet neural networks for omnidirectional mobile robot manipulator. ISA Trans. 2021, in press. [CrossRef]

36. Neythalath, N.; Søndergaard, A.; Bærentzen, J.A. Adaptive robotic manufacturing using higher order knowledge systems. Autom. Constr. 2021, 127, 103702. [CrossRef]

37. Perkins, I.; Skitmore, M. Three-dimensional printing in the construction industry: A review. Int. J. Constr. Manag. 2015, 15, 1-9. [CrossRef]

38. Tibaut, A.; Rebolj, D.; Nekrep Perc, M. Interoperability requirements for automated manufacturing systems in construction. $J$. Intell. Manuf. 2013, 27, 251-262. [CrossRef]

39. Craveiro, F.; Duarte, J.P.; Bartolo, H.; Bartolo, P.J. Additive manufacturing as an enabling technology for digital construction: A perspective on Construction 4.0. Autom. Constr. 2019, 103, 251-267. [CrossRef]

40. Lim, J.H.; Weng, Y.; Pham, Q.C. 3D printing of curved concrete surfaces using Adaptable Membrane Formwork. Constr. Build. Mater. 2020, 232, 117075. [CrossRef]

41. Ma, G.; Wang, L.; Ju, Y. State-of-the-art of 3D printing technology of cementitious material-An emerging technique for construction. Sci. China Technol. Sci. 2018, 61, 475-495. [CrossRef] 
42. Bhatt, P.M.; Malhan, R.K.; Shembekar, A.V.; Yoon, Y.J.; Gupta, S.K. Expanding capabilities of additive manufacturing through use of robotics technologies: A survey. Addit. Manuf. 2020, 31, 100933. [CrossRef]

43. Song, X.; Pan, Y.; Chen, Y. Development of a low-cost parallel kinematic machine for multidirectional additive manufacturing. J. Manuf. Sci. Eng. Trans. ASME 2015, 137, 021005. [CrossRef]

44. Zhang, G.Q.; Mondesir, W.; Martinez, C.; Li, X.; Fuhlbrigge, T.A.; Bheda, H. Robotic additive manufacturing along curved surface-A step towards free-form fabrication. In Proceedings of the 2015 IEEE Conference on Reobotics and Biomimetics, Zhuhai, China, 6-9 December 2015; pp. 721-726. [CrossRef]

45. Al Rashid, A.; Khan, S.A.; Al-Ghamdi, S.G.; Koç, M. Additive manufacturing: Technology, applications, markets, and opportunities for the built environment. Autom. Constr. 2020, 118, 103268. [CrossRef]

46. Bhatt, P.M.; Kabir, A.M.; Peralta, M.; Bruck, H.A.; Gupta, S.K. A robotic cell for performing sheet lamination-based additive manufacturing. Addit. Manuf. 2019, 27, 278-289. [CrossRef]

47. Jeong, W.; Kwon, Y.S.; Kim, D. Three-dimensional printing of tungsten structures by directed energy deposition. Mater. Manuf. Process. 2019, 34, 986-992. [CrossRef]

48. Bhatt, P.M.; Peralta, M.; Bruck, H.A.; Gupta, S.K. Robot assisted additive manufacturing of thin multifunctional structures. In Proceedings of the 13th International Manufacturing Science and Engineering Conference, College Station, TX, USA, 18-22 June 2018. [CrossRef]

49. Cullen, A.T.; Price, A.D. Fabrication of 3D conjugated polymer structures via vat polymerization additive manufacturing. Smart Mater. Struct. 2019, 28, 104007. [CrossRef]

50. Wu, P.; Wang, J.; Wang, X. A critical review of the use of 3-D printing in the construction industry. Autom. Constr. 2016, 68, 21-31. [CrossRef]

51. Carneau, P.; Mesnil, R.; Roussel, N.; Baverel, O. Additive manufacturing of cantilever-From masonry to concrete 3D printing Autom. Constr. 2020, 116, 103184. [CrossRef]

52. Vantyghem, G.; Ooms, T.; de Corte, W. VoxelPrint: A Grasshopper plug-in for voxel-based numerical simulation of concrete printing. Autom. Constr. 2021, 122, 103469. [CrossRef]

53. Özalp, F.; Yilmaz, H.D. Fresh and Hardened Properties of 3D High-Strength Printing Concrete and Its Recent Applications. Iran. J. Sci. Technol.-Trans. Civ. Eng. 2020, 44, 319-330. [CrossRef]

54. Jovanović, M.; Raković, M.; Tepavčević, B.; Borovac, B.; Nikolić, M. Robotic fabrication of freeform foam structures with quadrilateral and puzzle shaped panels. Autom. Constr. 2017, 74, 28-38. [CrossRef]

55. Kontovourkis, O.; Tryfonos, G. Robotic 3D clay printing of prefabricated non-conventional wall components based on a parametric-integrated design. Autom. Constr. 2020, 110, 103005. [CrossRef]

56. El Sakka, F.; Hamzeh, F. 3D concrete printing in the service of lean construction. In Proceedings of the 25th Annual Conference of the International Group for Lean Construction, Heraklion, Greece, 9-12 July 2017; pp. 781-788. [CrossRef]

57. Malé-Alemany, M. The Potential of Additive Manufacturing in Architecture: Towards a New Paradigm for Design and Construction, UPC-ETSAB; Universitat Politècnica de Catalunya: Barcelona, Spain, 2015.

58. Tay, Y.W.D.; Panda, B.; Paul, S.C.; Noor Mohamed, N.A.; Tan, M.J.; Leong, K.F. 3D printing trends in building and construction industry: A review. Virtual Phys. Prototyp. 2017, 12, 261-276. [CrossRef]

59. Al Jassmi, H.; Al Najjar, F.; Mourad, A.H.I. Large-Scale 3D Printing: The Way Forward. IOP Conf. Ser. Mater. Sci. Eng. 2018, 324, 012088. [CrossRef]

60. Delgado Camacho, D.; Clayton, P.; O’Brien, W.J.; Seepersad, C.; Juenger, M.; Ferron, R.; Salamone, S. Applications of additive manufacturing in the construction industry-A forward-looking review. Autom. Constr. 2018, 89, 110-119. [CrossRef]

61. Ghaffar, S.H.; Corker, J.; Fan, M. Additive manufacturing technology and its implementation in construction as an eco-innovative solution. Autom. Constr. 2018, 93, 1-11. [CrossRef]

62. Wangler, T.; Lloret, E.; Reiter, L.; Hack, N.; Gramazio, F.; Kohler, M.; Bernhard, M.; Dillenburger, B.; Buchli, J.; Roussel, N.; et al Digital Concrete: Opportunities and Challenges. RILEM Tech. Lett. 2016, 1, 67. [CrossRef]

63. Doely, P.K. 3D Printing: A New Dimension in Construction. Available online: http://fwhtlaw.com/briefing-papers/3d-printingnew-dimension-construction/ (accessed on 9 February 2022).

64. Duballet, R.; Baverel, O.; Dirrenberger, J. Classification of building systems for concrete 3D printing. Autom. Constr. 2017, 83, 247-258. [CrossRef]

65. Marijnissen, M.P.A.; van der Zee, A. 3D Concrete Printing in Architecture. Mater. Stud. Methodol. 2016, 2, $299-308$.

66. Salet, T.A.M.; Ahmed, Z.Y.; Bos, F.P.; Laagland, H.L.M. Design of a 3D printed concrete bridge by testing*. Virtual Phys. Prototyp. 2018, 13, 222-236. [CrossRef]

67. Xu, J.; Ding, L.; Love, P.E.D. Digital reproduction of historical building ornamental components: From 3D scanning to 3D printing. Autom. Constr. 2017, 76, 85-96. [CrossRef]

68. Furet, B.; Poullain, P.; Garnier, S. 3D printing for construction based on a complex wall of polymer-foam and concrete. Addit. Manuf. 2019, 28, 58-64. [CrossRef]

69. Vantyghem, G.; de Corte, W.; Shakour, E.; Amir, O. 3D printing of a post-tensioned concrete girder designed by topology optimization. Autom. Constr. 2020, 112, 103084. [CrossRef]

70. Cohen, Z.; Carlson, N. Piling and pressing: Towards a method of 3D printing reinforced concrete columns. Constr. Robot. 2020, 4 , 61-73. [CrossRef] 
71. Lublasser, E.; Adams, T.; Vollpracht, A.; Brell-Cokcan, S. Robotic application of foam concrete onto bare wall elements-Analysis, concept and robotic experiments. Autom. Constr. 2018, 89, 299-306. [CrossRef]

72. Kwon, H. Experimentation and Analysis of Contour Crafting (CC) Process Using Uncured Ceramic Materials; University of Southern California: Los Angeles, CA, USA, 2002; p. 213.

73. Lafhaj, Z.; Rabenantoandro, A.Z.; el Moussaoui, S.; Dakhli, Z.; Youssef, N. Experimental approach for printability assessment: Toward a practical decision-making framework of printability for cementitious materials. Buildings 2019, 9, 245. [CrossRef]

74. Zhang, X.; Li, M.; Lim, J.H.; Weng, Y.; Tay, Y.W.D.; Pham, H.; Pham, Q.C. Large-scale 3D printing by a team of mobile robots. Autom. Constr. 2018, 95, 98-106. [CrossRef]

75. Rivera, R.G.; Alvarado, R.G.; Martínez-Rocamora, A.; Cheein, F.A. A comprehensive performance evaluation of different mobile manipulators used as displaceable 3D printers of building elements for the construction industry. Sustainanility 2020, $12,4378$. [CrossRef]

76. Nerella, V.N.; Mechtcherine, V. Studying the Printability of Fresh Concrete for Formwork-Free Concrete Onsite 3D Printing Technology (CONPrint3D); Elsevier Inc.: Amsterdam, The Netherlands, 2019; ISBN 9780128154816.

77. Mathur, R. 3D Printing in Architecture. IJISET-Int. J. Innov. Sci. Eng. Technol. Impact Factor 2016, 3, 583-591.

78. Duballet, R.; Baverel, O.; Dirrenberger, J. Space Truss Masonry Walls With Robotic Mortar Extrusion. Structures 2019, 18, 41-47. [CrossRef]

79. Wolfs, R.J.M.; Bos, F.P.; Van Strien, E.C.F. A Real-Time Height Measurement and Feedback System for 3D Concrete Printing. In High Tech Concrete: Where Technology and Engineering Meet; Springer: Berlin/Heidelberg, Germany, 2018; Volume 1, pp. 1-10. ISBN 978-3-319-59470-5.

80. De Schutter, G.; Lesage, K.; Mechtcherine, V.; Nerella, V.N.; Habert, G.; Agusti-Juan, I. Vision of 3D printing with concreteTechnical, economic and environmental potentials. Cem. Concr. Res. 2018, 112, 25-36. [CrossRef]

81. Krimi, I.; Lafhaj, Z.; Ducoulombier, L. Prospective study on the integration of additive manufacturing to building industry-Case of a French construction company. Addit. Manuf. 2017, 16, 107-114. [CrossRef]

82. Buswell, R.A.; Leal de Silva, W.R.; Jones, S.Z.; Dirrenberger, J. 3D printing using concrete extrusion: A roadmap for research. Cem. Concr. Res. 2018, 112, 37-49. [CrossRef]

83. Malaeb, Z.; AlSakka, F.; Hamzeh, F. 3D Concrete Printing; Elsevier Inc.: Amsterdam, The Netherlands, 2019 ; ISBN 9780128154816.

84. Allouzi, R.; Al-azhari, W.; Allouzi, R. Conventional Construction and 3D Printing: A Comparison Study on Material Cost in Jordan. J. Eng. 2020, 2020, 1424682. [CrossRef]

85. Mechtcherine, V.; Grafe, J.; Nerella, V.N.; Spaniol, E.; Hertel, M.; Füssel, U. 3D-printed steel reinforcement for digital concrete construction-Manufacture, mechanical properties and bond behaviour. Constr. Build. Mater. 2018, 179, 125-137. [CrossRef]

86. Cesaretti, G.; Dini, E.; de Kestelier, X.; Colla, V.; Pambaguian, L. Building components for an outpost on the Lunar soil by means of a novel 3D printing technology. Acta Astronaut. 2014, 93, 430-450. [CrossRef]

87. Bedarf, P.; Dutto, A.; Zanini, M.; Dillenburger, B. Foam 3D printing for construction: A review of applications, materials, and processes. Autom. Constr. 2021, 130, 103861. [CrossRef]

88. Asprone, D.; Auricchio, F.; Menna, C.; Mercuri, V. 3D printing of reinforced concrete elements: Technology and design approach. Constr. Build. Mater. 2018, 165, 218-231. [CrossRef]

89. Taha, N.; Walzer, A.N.; Ruangjun, J.; Lloret-fritschi, E.; Gramazio, F.; Kohler, M. Robotic AeroCrete A novel robotic spraying and surface treatment technology for the production of slender reinforced concrete elements. In Proceedings of the 37 Education and Research in Computer Aided Architectural Design in Europe and XXIII Iberoamerican Society of Digital Graphics, Joint Conference (N. 1), Porto, Portugal, 11-13 September 2019; Volume 3, pp. 245-254.

90. Kreiger, E.L.; Kreiger, M.A.; Case, M.P. Development of the construction processes for reinforced additively constructed concrete. Addit. Manuf. 2019, 28, 39-49. [CrossRef]

91. Ji, G.; Ding, T.; Xiao, J.; Du, S.; Li, J.; Duan, Z. A 3D printed ready-mixed concrete power distribution substation: Materials and construction technology. Materials 2019, 12, 1540. [CrossRef]

92. Banda-Pérez, P.; García-Alvarado, R.; Muñoz-Sanguinetti, C. Architectural Digital Design for 3D Printing Housing: Search for 3D Printing in Construction Trends for a Design Methodology. In Proceedings of the XXV International Conference of the Iberoamerican Society of Digital Graphics, São Paulo, Brazil, 8-12 November 2021; pp. 1409-1422.

93. Collado, R.; Valencia, P.; Luis, J.; Rodríguez, M.; Montes, M.; Guillermo, J. Investigación Sobre Construcción 3d y Sus Aplicaciones; Universitat Politècnica de València: Valencia, Spain, 2018; pp. 190-197. [CrossRef]

94. Wolfs, R.J.M.; Salet, T.A.M. 3D Printing of Concrete Structures. Master's Thesis, Eindhoven University of Technology, Eindhoven, The Netherlands, 2015.

95. Dritsas, S.; Soh, G.S. Building robotics design for construction. Constr. Robot. 2018, 3, 1-10. [CrossRef]

96. González Böhme, L.F.; Quitral Zapata, F.; Maino Ansaldo, S. Roboticus tignarius: Robotic reproduction of traditional timber joints for the reconstruction of the architectural heritage of Valparaíso. Constr. Robot. 2017, 1, 61-68. [CrossRef]

97. Eversmann, P.; Gramazio, F.; Kohler, M. Robotic prefabrication of timber structures: Towards automated large-scale spatial assembly. Constr. Robot. 2017, 1, 49-60. [CrossRef]

98. Stumm, S.; Devadass, P.; Brell-Cokcan, S. Haptic programming in construction. Constr. Robot. 2018, 2, 3-13. [CrossRef]

99. Siddika, A.; Al Mamun, M.A.; Ferdous, W.; Saha, A.K.; Alyousef, R. 3D-printed concrete: Applications, performance, and challenges. J. Sustain. Cem. Mater. 2020, 9, 127-164. [CrossRef] 
100. Więckowski, A. "JA-WA"-A wall construction system using unilateral material application with a mobile robot. Autom. Constr. 2017, 83, 19-28. [CrossRef]

101. Paul, S.C.; van Zijl, G.P.A.G.; Gibson, I. A review of 3D concrete printing systems and materials properties: Current status and future research prospects. Rapid Prototyp. J. 2018, 24, 784-798. [CrossRef]

102. Khatri, N.R.; Islam, M.N.; Cao, P.-F.; Advincula, R.C.; Choi, W.; Jiang, Y. Integrating helicoid channels for passive control of fiber alignment in direct-write 3D printing. Addit. Manuf. 2021, 48, 102419. [CrossRef]

103. Barnett, E.; Gosselin, C. Large-scale 3D printing with a cable-suspended robot. Addit. Manuf. 2015, 7, 27-44. [CrossRef]

104. Mechtcherine, V.; Nerella, V.N.; Will, F.; Näther, M.; Otto, J.; Krause, M. Large-scale digital concrete construction-CONPrint3D concept for on-site, monolithic 3D-printing. Autom. Constr. 2019, 107, 102933. [CrossRef]

105. Keating, S.J.; Leland, J.C.; Cai, L.; Oxman, N. Toward site-specific and self-sufficient robotic fabrication on architectural scales. Sci. Robot. 2017, 2, 15. [CrossRef]

106. Demont, L.; Ducoulombier, N.; Mesnil, R.; Caron, J.F. Flow-based pultrusion of continuous fibers for cement-based composite material and additive manufacturing: Rheological and technological requirements. Compos. Struct. 2021, 262, 113564. [CrossRef]

107. Classen, M.; Ungermann, J.; Sharma, R. Additive manufacturing of reinforced concrete-development of a 3D printing technology for cementitious composites with metallic reinforcement. Appl. Sci. 2020, 10, 3791. [CrossRef]

108. Bong, S.H.; Nematollahi, B.; Nazari, A.; Xia, M.; Sanjayan, J. Method of optimisation for ambient temperature cured sustainable geopolymers for 3D printing construction applications. Materials 2019, 16, 902. [CrossRef]

109. Paul, S.C.; Tay, Y.W.D.; Panda, B.; Tan, M.J. Fresh and hardened properties of 3D printable cementitious materials for building and construction. Arch. Civ. Mech. Eng. 2018, 18, 311-319. [CrossRef]

110. Cho, S.; Kruger, J.; Zeranka, S.; van Zijl, G. 3D Printable Concrete Technology and Mechanics. Concr. Bet. 2019, 158, 11-18.

111. Le, T.T.; Austin, S.A.; Lim, S.; Buswell, R.A.; Law, R.; Gibb, A.G.F.; Thorpe, T. Hardened properties of high-performance printing concrete. Cem. Concr. Res. 2012, 42, 558-566. [CrossRef]

112. Feng, P.; Meng, X.; Chen, J.-F.; Ye, L. Mechanical properties of structures 3D printed with cementitious powders. Constr. Build. Mater. 2015, 93, 486-497. [CrossRef]

113. Van Dijk, N.P.; Maute, K.; Langelaar, M.; van Keulen, F. Level-set methods for structural topology optimization: A review. Struct. Multidiscip. Optim. 2013, 48, 437-472. [CrossRef]

114. Sigmund, O.; Maute, K. Topology optimization approaches: A comparative review. Struct. Multidiscip. Optim. 2013, 48, 1031-1055. [CrossRef]

115. Jin, Y.; Du, J.; Ma, Z.; Liu, A.; He, Y. An optimization approach for path planning of high-quality and uniform additive manufacturing. Int. J. Adv. Manuf. Technol. 2017, 92, 651-662. [CrossRef]

116. Jin, G.Q.; Li, W.D.; Gao, L. An adaptive process planning approach of rapid prototyping and manufacturing. Robot. Comput. Integr. Manuf. 2013, 29, 23-38. [CrossRef]

117. Zhao, H.; Gu, F.; Huang, Q.X.; Garcia, J.; Chen, Y.; Tu, C.; Benes, B.; Zhang, H.; Cohen-Or, D.; Chen, B. Connected fermat spirals for layered fabrication. ACM Trans. Graph. 2016, 35, 1-10. [CrossRef]

118. Jin, Y.A.; He, Y.; Fu, J.Z.; Gan, W.F.; Lin, Z.W. Optimization of tool-path generation for material extrusion-based additive manufacturing technology. Addit. Manuf. 2014, 1, 32-47. [CrossRef]

119. Giberti, H.; Sbaglia, L.; Urgo, M. A path planning algorithm for industrial processes under velocity constraints with an application to additive manufacturing. J. Manuf. Syst. 2017, 43, 160-167. [CrossRef]

120. Thompson, B.; Yoon, H. Efficient path planning algorithm for additive manufacturing systems. IEEE Trans. Compon. Packag. Manuf. Technol. 2014, 4, 1555-1563. [CrossRef]

121. Ganganath, N.; Cheng, C.T.; Fok, K.Y.; Tse, C.K. Trajectory planning for 3D printing: A revisit to traveling salesman problem. In Proceedings of the 2016 2nd International Conference on Control, Automation and Robotics (ICCAR), Hong Kong, China, 28-30 April 2016; pp. 287-290. [CrossRef]

122. Xie, F.; Chen, L.; Li, Z.; Tang, K. Path smoothing and feed rate planning for robotic curved layer additive manufacturing. Robot. Comput. Integr. Manuf. 2020, 65, 101967. [CrossRef]

123. Li, B.; Zhang, H.; Ye, P.; Wang, J. Trajectory smoothing method using reinforcement learning for computer numerical control machine tools. Robot. Comput. Integr. Manuf. 2020, 61, 101847. [CrossRef]

124. Yang, J.; Li, D.; Ye, C.; Ding, H. An analytical C3 continuous tool path corner smoothing algorithm for $6 \mathrm{R}$ robot manipulator. Robot. Comput. Integr. Manuf. 2020, 64, 101947. [CrossRef]

125. Calleja, A.; Tabernero, I.; Ealo, J.A.; Campa, F.J.; Lamikiz, A.; de Lacalle, L.N.L. Feed rate calculation algorithm for the homogeneous material deposition of blisk blades by 5-axis laser cladding. Int. J. Adv. Manuf. Technol. 2014, 74, 1219-1228. [CrossRef]

126. He, S.; Yan, C.; Deng, Y.; Lee, C.H.; Zhou, X. A tolerance constrained G2 continuous path smoothing and interpolation method for industrial SCARA robots. Robot. Comput. Integr. Manuf. 2020, 63, 101907. [CrossRef]

127. Chen, C.S.; Chen, S.K. Synchronization of tool tip trajectory and attitude based on the surface characteristics of workpiece for 6-DOF robot manipulator. Robot. Comput. Integr. Manuf. 2019, 59, 13-27. [CrossRef]

128. Fok, K.Y.; Cheng, C.T.; Ganganath, N.; Iu, H.H.C.; Tse, C.K. Accelerating 3D Printing Process Using an Extended Ant Colony Optimization Algorithm. In Proceedings of the 2018 IEEE International Symposium on Circuits and Systems (ISCAS), Florence, Italy, 27-30 May 2018. [CrossRef] 
129. Fok, K.Y.; Ganganath, N.; Cheng, C.T.; Iu, H.H.C.; Tse, C.K. A Nozzle Path Planner for 3-D Printing Applications. IEEE Trans. Ind. Inform. 2020, 16, 6313-6323. [CrossRef]

130. Chalvin, M.; Campocasso, S.; Hugel, V.; Baizeau, T. Layer-by-layer generation of optimized joint trajectory for multi-axis robotized additive manufacturing of parts of revolution. Robot. Comput. Integr. Manuf. 2020, 65, 101960. [CrossRef]

131. Li, S.; Liu, L.; Peng, C. A review of performance-oriented architectural design and optimization in the context of sustainability: Dividends and challenges. Sustainability 2020, 12, 1427. [CrossRef]

132. Lim, S.; Buswell, R.A.; Valentine, P.J.; Piker, D.; Austin, S.A.; de Kestelier, X. Modelling curved-layered printing paths for fabricating large-scale construction components. Addit. Manuf. 2016, 12, 216-230. [CrossRef]

133. Farouki, R.T.; Koenig, T.; Tarabanis, K.A.; Korein, J.U.; Batchelder, J.S. Path planning with offset curves for layered fabrication processes. J. Manuf. Syst. 1995, 14, 355-368. [CrossRef]

134. Reiter, L.; Wangler, T.; Roussel, N.; Flatt, R.J. The role of early age structural build-up in digital fabrication with concrete. Cem. Concr. Res. 2018, 112, 86-95. [CrossRef]

135. Bard, J.; Cupkova, D.; Washburn, N.; Zeglin, G. Robotic concrete surface finishing: A moldless approach to creating thermally tuned surface geometry for architectural building components using Profile-3D-Printing. Constr. Robot. 2018, 2, 53-65. [CrossRef]

136. Nematollahi, B.; Xia, M.; Sanjayan, J. Current Progress of 3D Concrete Printing Technologies. In Proceedings of the ISARC201734th International Symposium on Automation and Robotics in Construction, Taipei, Taiwan, 1 July 2017.

137. Anjum, T.; Dongre, P.; Misbah, F.; Nanyam, V.P.S.N. Purview of 3DP in the Indian Built Environment Sector. Procedia Eng. 2017, 196, 228-235. [CrossRef]

138. Bos, F.; Ahmed, Z.; Wolfs, R.; Salet, T. 3D Printing Concrete with Reinforcement. In High Tech Concrete: Where Technology and Engineering Meet; Springer: Berlin/Heidelberg, Germany, 2018; Volume 1, ISBN 978-3-319-59470-5.

139. Jagoda, J.; Diggs-McGee, B.; Kreiger, M.; Schuldt, S. The viability and simplicity of 3D-Printed construction: A military case study. Infrastructures 2020, 5, 35. [CrossRef]

140. Alwi, A.; Karayiannis, S.; Starkey, B.; Gardner, M.; Reodique, K.; Varley, T. Contrucktion: MegaScale 3D Printing-Group 1; University of Surrey: Guildford, UK, 2013.

141. García de Soto, B.; Agustí-Juan, I.; Hunhevicz, J.; Joss, S.; Graser, K.; Habert, G.; Adey, B.T. Productivity of digital fabrication in construction: Cost and time analysis of a robotically built wall. Autom. Constr. 2018, 92, 297-311. [CrossRef]

142. Bosscher, P.; Williams, R.L.; Bryson, L.S.; Castro-Lacouture, D. Cable-suspended robotic contour crafting system. Autom. Constr. 2007, 17, 45-55. [CrossRef]

143. Martínez-Rocamora, A.; García-Alvarado, R.; Casanova-Medina, E.; González-Böhme, L.F.; Auat-Cheein, F. (Forthcoming) Parametric programming of 3D printed curved walls for cost-efficient building design. J. Constr. Eng. Manag. 2020, 146, 04020039. [CrossRef]

144. Wolfs, R.J.M.; Suiker, A.S.J. Structural failure during extrusion-based 3D printing processes. Int. J. Adv. Manuf. Technol. 2019, 104, 565-584. [CrossRef]

145. Diggs-McGee, B.N.; Kreiger, E.L.; Kreiger, M.A.; Case, M.P. Print time vs. elapsed time: A temporal analysis of a continuous printing operation for additive constructed concrete. Addit. Manuf. 2019, 28, 205-214. [CrossRef]

146. Carneau, P.; Baverel, O.; Mesnil, R.; Roussel, N. An exploration of 3d printing design space inspired by masonry. In Proceedings of the IASS Annual Symposium 2019-Structural Membranes 2019, Barcelona, Spain, 6-10 October 2019; pp. 1-10.

147. Agustí-Juan, I.; Habert, G. Environmental design guidelines for digital fabrication. J. Clean. Prod. 2017, 142, 2780-2791. [CrossRef]

148. Gomaa, M.; Carfrae, J.; Goodhew, S.; Jabi, W.; Veliz Reyes, A. Thermal performance exploration of 3D printed cob. Archit. Sci. Rev. 2019, 62, 230-237. [CrossRef]

149. Ibrahim, M.M. 3D printed architecture. A new practical frontier in construction methods. In Proceedings of the ASCAAD 2016-Parametricism vs. Materialism: Evolution of Digital Technologies for Development, London, UK, 7-8 November 2016; pp. 169-178.

150. Fischer, T.; Herr, C.M. Parametric customisation of a 3D concrete printed pavilion. In Proceedings of the CAADRIA 2016, 21st International Conference on Computer-Aided Architectural Design Research in Asia-Living Systems and Micro-Utopias: Towards Continuous Designing, Melbourne, Australia, 30 March-2 April 2016; pp. 549-558.

151. Davtalab, O.; Kazemian, A.; Khoshnevis, B. Perspectives on a BIM-integrated software platform for robotic construction through Contour Crafting. Autom. Constr. 2018, 89, 13-23. [CrossRef]

152. Nadal, A.; Pavón, J.; Liébana, O. 3D printing for construction: A procedural and material-based approach. Inf. La Constr. 2017, 69, 193. [CrossRef]

153. Hwang, D.; Khoshnevis, B. An Innovative Construction Process-Contour. In Proceedings of the 22nd ISARC, Ferrara, Italy, 11-14 September 2005.

154. Bukkanatnam, S.; Clark, B. Dynamic modeling and monitoring of contour crafting-An extrusion-based layered manufacturing process. J. Manuf. Sci. Eng. Trans. ASME 2007, 129, 135-142. [CrossRef]

155. Khoshnevis, B.; Carlson, A.; Leach, N.; Thangavelu, M. Contour crafting simulation plan for lunar settlement infrastructure buildup. In Proceedings of the Thirteenth ASCE Aerospace Division Conference on Engineering, Science, Construction, and Operations in Challenging Environments, and the 5th NASA/ASCE Workshop On Granular Materials in Space Exploration, Pasadena, CA, USA, 15-18 April 2012; pp. 1458-1467. [CrossRef] 
156. Jeon, K.-H.; Park, M.-B.; Kang, M.-K.; Kim, J.-H. Development of an automated freeform construction system and its construction materials. In Proceedings of the ISARC-International Symposium on Automation and Robotics in Construction, Montréal, QC, Canada, 11-15 August 2013; pp. 1-7.

157. Leach, N.; Carlson, A.; Khoshnevis, B.; Thangavelu, M. Robotic Construction by Contour Crafting: The Case of Lunar Construction. Int. J. Archit. Comput. 2012, 10, 423-438. [CrossRef]

158. Feng, L.; Yuhong, L. Study on the Status Quo and Problems of 3D Printed Buildings in China. Glob. J. Hum.-Soc. Sci. 2014, 14, 1-4.

159. Perrot, A.; Rangeard, D.; Pierre, A. Structural built-up of cement-based materials used for 3D-printing extrusion techniques. Mater. Struct. Constr. 2016, 49, 1213-1220. [CrossRef]

160. Hager, I.; Golonka, A.; Putanowicz, R. 3D Printing of Buildings and Building Components as the Future of Sustainable Construction? Procedia Eng. 2016, 151, 292-299. [CrossRef]

161. Raspall, F.; Bañón, C. vMESH: How to print Architecture? Blucher Des. Proc. 2016, 3, 394-398. [CrossRef]

162. Marchment, T.; Xia, M.; Dodd, E.; Sanjayan, J.; Nematollahi, B. Effect of delay time on the mechanical properties of extrusion-based 3D printed concrete. In Proceedings of the 34rd ISARC, Taipei, Taiwan, 28 June-1 July 2017; pp. 240-245. [CrossRef]

163. Sakin, M.; Kiroglu, Y.C. 3D Printing of Buildings: Construction of the Sustainable Houses of the Future by BIM. Energy Procedia 2017, 134, 702-711. [CrossRef]

164. Anton, A.; Abdelmahgoub, A. Ceramic Components-Computational Design for Bespoke Robotic 3D Printing on Curved Support. In Proceedings of the 36th eCAADe Conference, Lodz, Poland, 19-21 September 2018; Volume 2, pp. 71-78.

165. Grassi, G.; Lupica Spagnolo, S.; Paoletti, I. Fabrication and durability testing of a 3D printed façade for desert climates. Addit. Manuf. 2019, 28, 439-444. [CrossRef]

166. Kruger, J.; Zeranka, S.; van Zijl, G. 3D concrete printing: A lower bound analytical model for buildability performance quantification. Autom. Constr. 2019, 106, 102904. [CrossRef]

167. Shakor, P.; Nejadi, S.; Paul, G. A study into the effect of different nozzles shapes and fibre-reinforcement in 3D printed mortar. Materials 2019, 12, 1708. [CrossRef]

168. Paolini, A.; Kollmannsberger, S.; Rank, E. Additive manufacturing in construction: A review on processes, applications, and digital planning methods. Addit. Manuf. 2019, 30, 100894. [CrossRef]

169. Tay, Y.W.D.; Li, M.Y.; Tan, M.J. Effect of printing parameters in 3D concrete printing: Printing region and support structures. J. Mater. Process. Technol. 2019, 271, 261-270. [CrossRef]

170. Xu, J.; Ding, L.; Cai, L.; Zhang, L.; Luo, H.; Qin, W. Volume-forming 3D concrete printing using a variable-size square nozzle. Autom. Constr. 2019, 104, 95-106. [CrossRef]

171. Marchment, T.; Sanjayan, J. Mesh reinforcing method for 3D Concrete Printing. Autom. Constr. 2020, 109, 102992. [CrossRef]

172. Nerella, V.N.; Krause, M.; Mechtcherine, V. Direct printing test for buildability of 3D-printable concrete considering economic viability. Autom. Constr. 2020, 109, 102986. [CrossRef]

173. Panda, B.; Paul, S.C.; Mohamed, N.A.N.; Tay, Y.W.D.; Tan, M.J. Measurement of tensile bond strength of 3D printed geopolymer mortar. Meas. J. Int. Meas. Confed. 2018, 113, 108-116. [CrossRef]

174. Khoshnevis, B.; Hwang, D.; Yao, K.-T.; Yeh, Z. Mega-scale fabrication by contour crafting Behrokh Khoshnevis. Int. J. Ind. Syst. Eng. 2006, 1, 301-306.

175. Duarte, J.; Shadi, N.; Negar, A. Designing Shelters for 3D-printing. In Proceedings of the Ecaade 2018: Virtual \& Physical Prototyping, Lodz, Poland, 17-21 September 2018; Volume 2, pp. 31-38.

176. Yin, H.; Qu, M.; Zhang, H.; Lim, Y.C. 3D Printing and Buildings: A Technology Review and Future Outlook. Technol. Archit. Des. 2018, 2, 94-111. [CrossRef]

177. Krause, M.; Otto, J.; Bulgakov, A.; Sayfeddine, D. Strategic optimization of 3D concrete printing using the method of CONPrint3D ${ }^{\circledR}$. In Proceedings of the 35th ISARC, Berlin, Germany, 20-25 July 2018.

178. Pascal, M.; Mathot, M.; Bos, F.; Coenders, J. Optimising 3D Printed Concrete Structures Using Topology Optimisation; Springer: Berlin/Heidelberg, Germany, 2018; ISBN 9783319594705.

179. Lim, S.; Buswell, R.; Le, T.; Wackrow, R.; Austin, S.; Gibb, A.; Thorpe, T. Development of a viable concrete printing process. In Proceedings of the ISARC2011-28th International Symposium on Automation and Robotics in Construction, Seoul, Korea, 29 June-2 July 2011; Volume 2, pp. 665-670.

180. Shakor, P.; Nejadi, S.; Paul, G.; Malek, S. Review of emerging additive manufacturing technologies in $3 \mathrm{~d}$ printing of cementitious materials in the construction industry. Front. Built Environ. 2019, 4, 85. [CrossRef]

181. Nan, C. A new machinecraft. Architectural robots. In Proceedings of the 20th International Conference of the Association for Computer-Aided Architectural Design Research in Asia (CAADRIA 2015), Daegu, Korea, 20-22 May 2015; pp. 745-754.

182. Ahmed, Z.Y.; Bos, F.P.; Wolfs, R.J.M.; Salet, T. Design considerations due to scale effects in $3 d$ concrete printing. In Proceedings of the 8th ASCAAD Conference, London, UK, 7-8 November 2016; pp. 1-10.

183. Kashani, A.; Ngo, T.D. Optimisation of mixture properties for 3D printing of geopolymer concrete. In Proceedings of the 35th ISARC, Berlin, Germany, 20-25 July 2018. [CrossRef]

184. Asprone, D.; Menna, C.; Bos, F.P.; Salet, T.A.M.; Mata-Falcón, J.; Kaufmann, W. Rethinking reinforcement for digital fabrication with concrete. Cem. Concr. Res. 2018, 112, 111-121. [CrossRef]

185. Khoshnevis, B. Automated construction by contour crafting-Related robotics and information technologies. Autom. Constr. 2004, 13, 5-19. [CrossRef] 
186. Gomaa, M.; Jabi, W.; Veliz Reyes, A.; Soebarto, V. 3D printing system for earth-based construction: Case study of cob. Autom. Constr. 2021, 124, 103577. [CrossRef] 